Article

\title{
Design, Synthesis, and Biological Evaluation of $N, N$-Disubstituted-4-arylthiazole-2-methylamine Derivatives as Cholesteryl Ester Transfer Inhibitors
}

\author{
Xinran Wang ${ }^{1,+}{ }^{,}$Xuehua Lin ${ }^{1,+}$, Xuanqi Xu ${ }^{2}$, Wei Li ${ }^{1}$, Lijuan Hao ${ }^{1}$, Chunchi Liu ${ }^{1}$, \\ Dongmei Zhao $^{1, *}$ (i) and Maosheng Cheng ${ }^{1}$ \\ 1 Key Laboratory of Structure-Based Drug Design \& Discovery of Ministry of Education, \\ Shenyang Pharmaceutical University, Shenyang 110016, China; wangxinrancai@163.com (X.W.); \\ lin_xuehua1995@163.com (X.L.); 15542173071@163.com (W.L.); 18341482606@163.com (L.H.); \\ liuchunchi1990@163.com (C.L.); mscheng@263.net (M.C.) \\ 2 Department of Chemistry, University of Wisconsin-Madison, Madison, WI 53715, USA; xxu53@wisc.edu \\ * Correspondence: medchemzhao@163.com; Tel.: +86-24-4352-0219 \\ $\dagger$ These authors contributed equally to this work.
}

Received: 15 October 2017; Accepted: 27 October 2017; Published: 7 November 2017

\begin{abstract}
Cholesteryl ester transfer protein (CETP) has been identified as a potential target for cardiovascular disease (CVD) for its important role in the reverse cholesteryl transfer (RCT) process. In our previous work, compound $\mathbf{5}$ was discovered as a moderate CETP inhibitor. The replacement of the amide linker by heterocyclic aromatics and then a series of $\mathrm{N}, \mathrm{N}$-substituted4-arylthiazole-2-methylamine derivatives were designed by utilizing a conformational restriction strategy. Thirty-six compounds were synthesized and evaluated for their CETP inhibitory activities. Structure-activity relationship studies indicate that electron donor groups substituted ring A, and electron-withdrawing groups at the 4-position of ring B were critical for potency. Among these compounds, compound 30 exhibited excellent CETP inhibitory activity $\left(\mathrm{IC}_{50}=0.79 \pm 0.02 \mu \mathrm{M}\right)$ in vitro and showed an acceptable metabolic stability.
\end{abstract}

Keywords: synthesis; $N, N$-disubstituted-4-arylthiazole-2-methylamine derivatives; CETP inhibitors

\section{Introduction}

Robust evidence suggests that a high level of low-density lipoprotein cholesterol (LDL-C) and a low level of high-density lipoprotein cholesterol (HDL-C) are closely associated with cardiovascular disease (CVD) [1-4]. Epidemiological studies have identified that each $1 \mathrm{mmol} / \mathrm{L}$ decrease of LDL-C reduces cardiovascular events by $22 \%$ [5]. In contrast to LDL-C, the risk of cardiovascular events will be reduced $2 \%$ to $3 \%$ for each $0.1 \mathrm{mg} / \mathrm{dL}$ increase in HDL-C [6]. Despite the successful utilization of statins in clinical treatment for reducing LDL-C levels, the residual risk of CVD events remains at high levels [7-10]. Plasma cholesteryl ester transfer protein (CETP), secreted mainly from the liver, plays a coordinating part in reverse cholesteryl transfer (RCT) that facilitates the transfer of triglyceride and cholesteryl ester (CE) between lipoproteins. The elevation of HDL-C via inhibiting CETP is an effective strategy for reducing the risk of cardiovascular events.

Up to now, several CETP inhibitors have been reported, and four of them have exhibited preeminent activity in phase III clinical trials (Figure 1) [11]. Torcetrapib was the first small molecule CETP inhibitor be appraised in the clinic. Early evidence has demonstrated that torcetrapib exhibited a dose-dependent increase of HDL-C greater than $100 \%$ and resulted in incremental LDL-C decreasing by up to $42 \%$ in human studies. However, torcetrapib was prematurely halted because of off-target hyperaldosteronism that lead to a $58 \%$ increase in deaths in the torcetrapib/atorvastatin group 
compared to the atorvastatin group [12-14]. Compared with torcetrapib, dalcetrapib showed modest CETP inhibition and no off-target effects. However, the phase III clinical trial was terminated due to the fact that dalcetrapib did not significantly decrease the risk of cardiovascular events [15,16]. Recently, DalCor Pharmaceuticals licensed dalcetrapib from Roche to conduct clinical trials for the treatment of acute coronary syndrome. The effect of evacetrapib on a reduction in CVD events was similar to trocetrapib, while avoiding torcetrapib's side effects [17]. Subsequently, the ACCELERATE trials of evacetrapib were terminated after just over two years, but the reason for failure has not been announced by Lilly. Anacetrapib is currently ongoing in phase III trials at Merck and Co. (Kenilworth, NJ, USA) for the treatment of coronary artery disease. More recently, Merck announced that anacetrapib significantly reduced the incidence of major coronary events, while anacetrapib's safety profile was generally consistent with that of previous studies of the drug. The phase II clinical trials demonstrated that AMG-899 seems to be free of the off-target effects of torcetrapib, effectively reduced LDL-C levels by $45.3 \%$, and increased HDL-C levels by $179.1 \%$ [18].

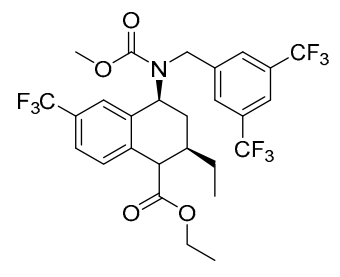

Torcetrapib (1)

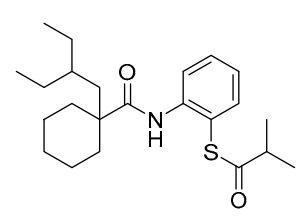

Dalcetrapib (2)

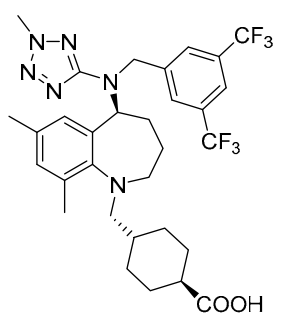

Evacetrapib (3)

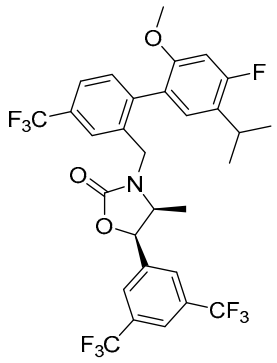

Anacetrapib (4)

Figure 1. Representative cholesteryl ester transfer protein (CETP) inhibitors.

In previous work, we found that compound 5 exhibited weak CETP inhibition activity. Based on the structure-activity relationship of compound 5, we replaced amide fragments with different heterocyclic aromatics and benzoheteroaromatics to decrease molecular flexibility while keeping the key pharmacophores invariant. As shown in Figure 2, the replacement of amide linker with seven fragments revealed a slight increase in activity, and the replacement of compound $\mathbf{1 7 d}$ with a 4-phenylthiazole side chain showed better CETP inhibition activities $\left(\mathrm{IC}_{50}=9.03 \pm 0.21 \mu \mathrm{M}\right)$. Under the consideration of the structural novelty and the difficulty of synthesis, compound $\mathbf{1 7} \mathbf{d}$ was selected as the leader for structure optimization, and a series of $N, N$-substituted-4-arylthiazole-2-methylamine derivatives were synthesized. Further optimization efforts in part A and part B led to the discovery of compound $30\left(\mathrm{IC}_{50}=0.79 \pm 0.02 \mu \mathrm{M}\right)$.

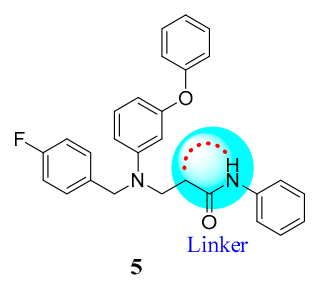

CETP IC $_{50}=24.78 \mathrm{uM}$

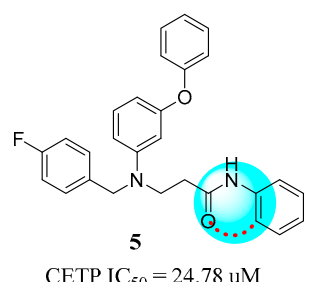

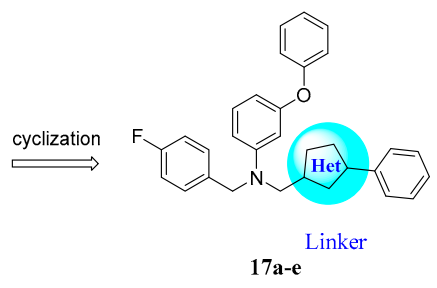

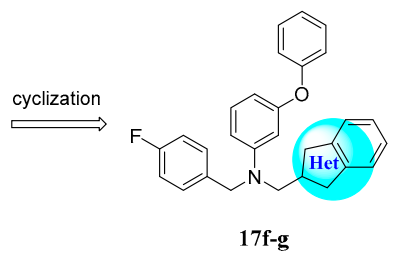

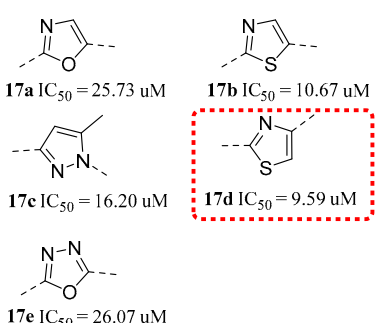

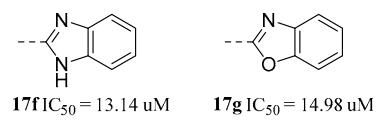

Figure 2. Design of $N, N$-substituted-aryl-methylamines. 


\section{Results and Discussion}

\subsection{Chemistry}

Compounds 17a-g were prepared according to Scheme 1 and ${ }^{1} \mathrm{H}-\mathrm{NMR},{ }^{13} \mathrm{C}-\mathrm{NMR}, \mathrm{HRMS}$ for these target compounds are gave in supplementary materials. The commercially available 2-amino-1-phenylethan-1-one hydrochloride (6) reacted with 2-chloroacetyl chloride to give 7. The resulting 7 underwent cyclization reactions, respectively, with $\mathrm{POCl}_{3}$ and Lawesson's reagent to produce 13a and 13b. The treatment of 8 with ethyl acetopyruvate achieved 9 in moderate yield. Then 9 was reacted with $\mathrm{NaBH}_{4}$ and, subsequently, $\mathrm{SOCl}_{2}$ to afford 13c. The key intermediate 11 was prepared by $\mathbf{1 0}$ with ethyl 2-amino-2-thioxoacetate in ethanol under reflux conditions. In the next step, 11 was treated with the same operation as $\mathbf{9}$ to obtain $\mathbf{1 3 d}$. Compounds $\mathbf{1 3 e - f}$ were respectively prepared from the cyclization of $\mathbf{1 2}, \mathbf{1 4}$, and 15 with different derivatives of chloroacetic acid. Compounds 16a-g were obtained by the nucleophilic substitution of 13a-g and 3-phenoxyaniline in the presence of $\mathrm{K}_{2} \mathrm{CO}_{3}$ and KI in DMF. The secondary amines 16a-g were treated with 1-(bromomethyl)-4-fluorobenzene to generate target compounds $17 \mathbf{a}-\mathbf{g}$.

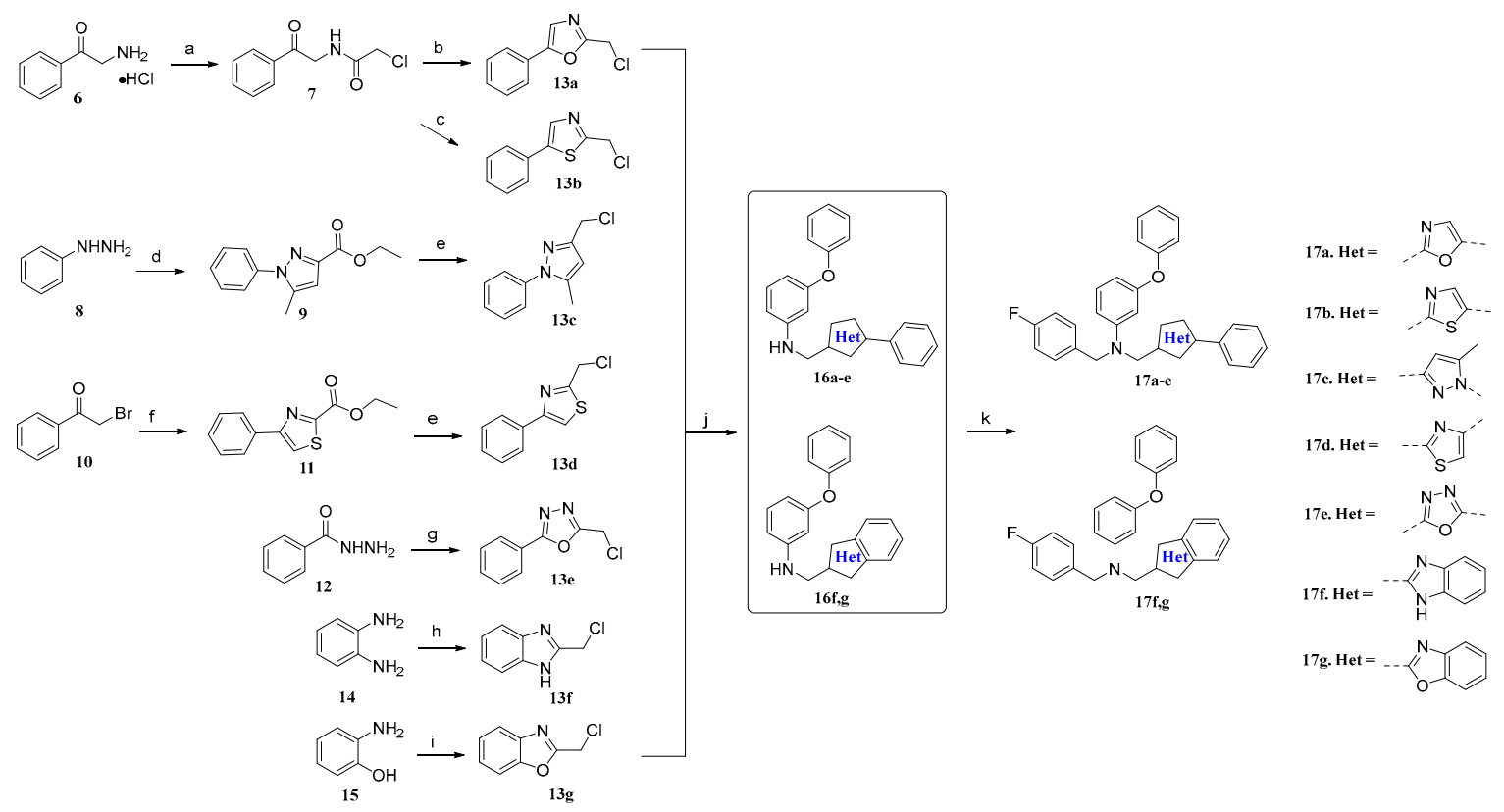

Scheme 1. Synthesis of target compounds 17a-g. Reagents and conditions: (a) 2-Chloroacetyl chloride, TEA, DCM, $0{ }^{\circ} \mathrm{C}, 62.9 \%$; (b) $\mathrm{POCl}_{3}, \mathrm{CH}_{3} \mathrm{CN}$, reflux, 66.2\%; (c) Lawesson's reagent, THF, reflux, $59.6 \%$; (d) Ethyl acetopyruvate, EtOH, reflux, 43.6\%; (e) (i) $\mathrm{NaBH}_{4}$, THF, r.t.; (ii) $\mathrm{SOCl}_{2}$, $\mathrm{DMF}$, r.t., 75.9 80.5\%; (f) Ethyl 2-amino-2-thioxoacetate, EtOH, reflux, 73.6\%; (g) 2-Chloroacetic acid, $\mathrm{POCl}_{3}$, reflux, 81.1\%; (h) Ethyl 2-chloroacetate, $\mathrm{HCl}, 110{ }^{\circ} \mathrm{C}, 91.3 \%$; (i) 2-Chloroacetyl chloride, p-TsOH, pyridine, chlorobenzene, reflux, 90.2\%; (j) 3-Phenoxyaniline, $\mathrm{K}_{2} \mathrm{CO}_{3}$, KI, DMF, r.t., 52.6 70.3\%; (k) 1-(Bromomethyl)-4-fluorobenzene, $\mathrm{K}_{2} \mathrm{CO}_{3}, \mathrm{KI}, \mathrm{DMF}$, r.t., $64.9 \sim 71.6 \%$.

The synthesis of compounds 21-49 was outlined in Scheme 2 and ${ }^{1} \mathrm{H}-\mathrm{NMR},{ }^{13} \mathrm{C}-\mathrm{NMR}$, HRMS for these target compounds are gave in supplementary materials. The intermediate 18 was prepared by the cyclization of 2-bromo-1-phenylethan-1-one with ethyl 2-amino-2-thioxoacetate in ethanol under reflux conditions. Then the ester function in 18 was reduced with $\mathrm{NaBH}_{4}$ and reacted subsequently with $\mathrm{SOCl}_{2}$ to afford 19. Compound 20 was obtained by the nucleophilic substitution of 19 and 3-phenoxyaniline in the presence of $\mathrm{K}_{2} \mathrm{CO}_{3}$ and $\mathrm{KI}$ in DMF. Intermediate 20 and 1-(bromomethyl)-4-fluorobenzene underwent a nucleophilic reaction to get target compounds 21 to 49 . 


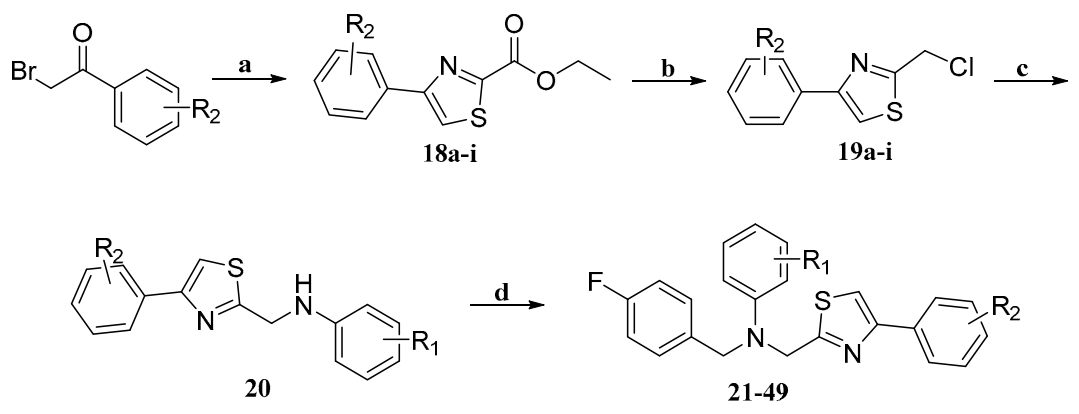

Scheme 2. Synthesis of target compounds 21 to 49. Reagents and conditions: (a) Ethyl 2-amino2-thioxoacetate, EtOH, reflux, 70.6 79.1\%; (b) (i) $\mathrm{NaBH}_{4}$, THF, r.t.; (ii) $\mathrm{SOCl}_{2}$, DMF, r.t., 75.9 80.5\%; (c) Corresponding anilines, $\mathrm{K}_{2} \mathrm{CO}_{3}, \mathrm{KI}, \mathrm{DMF}$, r.t., 52.6 70.3\%; (d) 1-(Bromomethyl)-4-fluorobenzene, $\mathrm{K}_{2} \mathrm{CO}_{3}, \mathrm{KI}, \mathrm{DMF}$, r.t., $64.9 \sim 71.6 \%$.

\subsection{In Vitro Activity and Structure-Activity Relationships}

The biological activity of $N, N$-disubstituted-aryl-methylamine derivatives and reference compound anacetrapib (4) against CETP was evaluated by a BODIPY-CE fluorescence assay with the CETP RP Activity Assay Kit (catalog \# RB-RPAK; Roar, New York, NY, USA). The results showed that most of the target compounds exhibit potent CETP inhibitory activity.

As shown in Table 1, 4-phenylthiazole (17d) revealed better activity than other links. Further optimization based on $N, N$-substituted-4-arylthiazole-2-methylamine scaffolding was underway, and in vitro activity against CETP is shown in Table 2. We investigated the relationship between various groups at the 2-position, 3-position, and 4-position of the benzene (Ring A) and the CETP inhibitory activity. The introduction of the 3,4-dimethoxy group $(\mathbf{2 2}, \mathbf{3 0}-\mathbf{3 3})$ was beneficial to activity. The replacement of hydrogen by trifluoromethoxy (23) and $N$-methyl-5-yl-pyrazole (29) at the 3-position was detrimental to activity. Changing the 3- $\mathrm{H}$ group to $3-\mathrm{OCH}_{3}(\mathbf{2 1})$ and $3-\mathrm{CF}_{3}(\mathbf{2 4})$ slightly decreased CETP inhibition activity. Thus, we could conclude that electron donor groups, in particular the 3,4-dimethoxy group, substituted in ring A were conducive to activity. Next, the effect of the aromatic ring on activity was investigated; then phenyl, 2-thienyl and $N$-methyl-5-yl-pyrazolyl were induced to modify ring A. Specifically, it was observed that the activity of compound 27 $\left(\mathrm{IC}_{50}=1.02 \pm 0.01 \mu \mathrm{M}\right)$ was a seven-fold improvement over compound $26\left(\mathrm{IC}_{50}=8.98 \pm 0.05 \mu \mathrm{M}\right)$ and an eight-fold improvement over compound $25\left(\mathrm{IC}_{50}=9.05 \pm 0.08 \mu \mathrm{M}\right)$. Compared to the phenyl-substituted ring A at the 3-position (26), 2-thienyl (28) and N-methyl-5-yl-pyrazolyl (29) showed no advantage. The results from the modification of the ring A moiety indicated that phenyl-substituted compounds were favorable for activity compared to thienyl and pyrazolyl, and the position of the phenyl group provided an important contribution to the inhibitory activity. However, the potency of compound $30\left(\mathrm{IC}_{50}=0.79 \pm 0.02 \mu \mathrm{M}\right.$ ) was superior to compound 27 , and, for that reason, the (3,4-dimethoxyl) phenyl fragment was chosen for further study of the relationship between ring B and the CETP inhibitory activity. For this purpose, another nineteen compounds, 31 to 49, were synthesized and evaluated for their activities. Compounds containing electron withdrawing groups (31 to 33 ) at the 4-position of ring B revealed significant improvement of activity compared to those compounds with electron donor groups (42 to 45). The nitro group at the 4-position of ring B (30) exhibited better potency of CETP inhibitory activity than that substituted at the 2-position (35) and the 3-position (34). The introduction of bromine (36), 1-methylpyrazole $(37,39)$, isoxazole (38), thiazole (40), and benzene (41) was tolerated, but 4-morpholinyl (49) led to a disappearance of activity. Replacing the nitro group on the 4-position of ring B with an ester side chain (48) caused nearly a 10-fold decrease of activity. Changing the 4- $\mathrm{NH}_{2}$ group (44) to a 4- $\mathrm{NHCOCH}_{3}$ group (46) showed a dramatic decrease in the activity; however, potency was recovered when modified by a $4-\mathrm{NHCOCF}_{3}$ group (45) was introduced. Based on these in vitro structure-activity relationshipstudies, we could speculate that 
electron-withdrawing groups at the 4-position of ring B provide an important contribution to the potency compared with electron withdrawing groups and bulkier rigid fragments.

Table 1. Structures and activities of compounds $17 \mathbf{a}$ to $\mathrm{g}$.
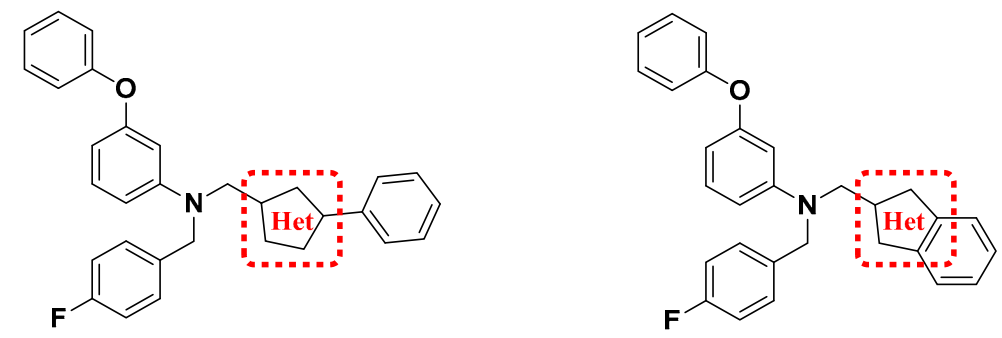

17a-e

$17 \mathbf{f}-\mathrm{g}$

\begin{tabular}{|c|c|c|c|c|c|}
\hline Compound & Het & $\mathrm{IC}_{50}(\mu \mathrm{M})$ & Compound & Het & $\mathrm{IC}_{50}(\mu \mathrm{M})$ \\
\hline $17 \mathbf{a}$ & & $25.73 \pm 0.41$ & $17 e$ & & $26.87 \pm 0.35$ \\
\hline $17 b$ & & $10.60 \pm 0.32$ & $17 f$ & & $13.68 \pm 0.63$ \\
\hline $17 c$ & & $17.10 \pm 0.44$ & $17 \mathrm{~g}$ & & $15.23 \pm 0.52$ \\
\hline $17 d$ & & $9.03 \pm 0.21$ & Anacetrapib ${ }^{a}$ & & $0.04 \pm 0.01$ \\
\hline
\end{tabular}

${ }^{a}$ Used as a positive control.

Table 2. Structures and activities of compounds 21 to 49 .

\begin{tabular}{|c|c|c|c|c|c|c|c|}
\hline Compound & $\mathbf{R}_{\mathbf{1}}$ & $\mathbf{R}_{2}$ & $\mathrm{IC}_{50}(\mu \mathrm{M})$ & Compound & $\mathbf{R}_{\mathbf{1}}$ & $\mathbf{R}_{2}$ & $\mathrm{IC}_{50}(\mu \mathrm{M})$ \\
\hline 21 & $3-\mathrm{OCH}_{3}$ & - & $13.96 \pm 0.11$ & 36 & 3,4- $\mathrm{diOCH}_{3}$ & $4-\mathrm{Br}$ & $8.96 \pm 0.15$ \\
\hline 22 & $3,4-\mathrm{diOCH}_{3}$ & - & $3.58 \pm 0.03$ & 37 & $3,4-\mathrm{diOCH}_{3}$ & & $4.02 \pm 0.05$ \\
\hline 23 & $3-\mathrm{OCF}_{3}$ & $4-\mathrm{NO}_{2}$ & $31.69 \pm 0.25$ & 38 & 3,4- $\mathrm{diOCH}_{3}$ & & $7.57 \pm 0.10$ \\
\hline 24 & $3-\mathrm{CF}_{3}$ & $4-\mathrm{NO}_{2}$ & $13.79 \pm 0.14$ & 39 & 3,4- $\mathrm{diOCH}_{3}$ & & $6.38 \pm 0.09$ \\
\hline 25 & 4-Ph & $4-\mathrm{NO}_{2}$ & $9.55 \pm 0.08$ & 40 & $3,4-\mathrm{diOCH}_{3}$ & & $6.03 \pm 0.04$ \\
\hline 26 & 3-Ph & $4-\mathrm{NO}_{2}$ & $8.98 \pm 0.05$ & 41 & $3,4-\mathrm{diOCH}_{3}$ & {$[3,4-a]$ benzene } & $3.51 \pm 0.06$ \\
\hline 27 & 2-Ph & $4-\mathrm{NO}_{2}$ & $1.02 \pm 0.01$ & 42 & $3,4-\mathrm{diOCH}_{3}$ & $4-\mathrm{CH}_{3}$ & $14.05 \pm 0.21$ \\
\hline 28 & & $4-\mathrm{NO}_{2}$ & $7.77 \pm 0.13$ & 43 & 3,4- $\mathrm{diOCH}_{3}$ & $4-\mathrm{OCH}_{3}$ & $10.96 \pm 0.31$ \\
\hline 29 & $3-$ & $4-\mathrm{NO}_{2}$ & $24.56 \pm 0.22$ & 44 & $3,4-\mathrm{diOCH}_{3}$ & $4-\mathrm{NH}_{2}$ & $16.66 \pm 0.23$ \\
\hline
\end{tabular}


Table 2. Cont.

\begin{tabular}{|c|c|c|c|c|c|c|c|}
\hline Compound & $\mathbf{R}_{1}$ & $\mathbf{R}_{2}$ & $\mathrm{IC}_{50}(\mu \mathrm{M})$ & Compound & $\mathbf{R}_{1}$ & $\mathbf{R}_{2}$ & $\mathrm{IC}_{50}(\mu \mathrm{M})$ \\
\hline 30 & 3,4- $\mathrm{diOCH}_{3}$ & $4-\mathrm{NO}_{2}$ & $0.79 \pm 0.02$ & 45 & 3,4- $\mathrm{diOCH}_{3}$ & $4-\mathrm{NHCOCF}_{3}$ & $15.30 \pm 0.17$ \\
\hline 31 & 3,4- $\mathrm{diOCH}_{3}$ & $4-\mathrm{F}$ & $2.46 \pm 0.06$ & 46 & 3,4- $\mathrm{diOCH}_{3}$ & $4-\mathrm{NHCOCH}_{3}$ & $>50^{\mathrm{b}}$ \\
\hline 32 & 3,4- $\mathrm{diOCH}_{3}$ & $4-\mathrm{CF}_{3}$ & $0.97 \pm 0.01$ & 47 & 3,4- $\mathrm{diOCH}_{3}$ & 4- 篮 & $3.54 \pm 0.03$ \\
\hline 33 & 3,4-diOCH 3 & $4-\mathrm{CN}$ & $1.50 \pm 0.03$ & 48 & 3,4- $\mathrm{diOCH}_{3}$ & 4-.on & $8.40 \pm 0.04$ \\
\hline 34 & 3,4- $\mathrm{diOCH}_{3}$ & $3-\mathrm{NO}_{2}$ & $1.38 \pm 0.07$ & 49 & 3,4- $\mathrm{diOCH}_{3}$ & 4-morpholinyl & $>50^{\mathrm{b}}$ \\
\hline 35 & 3,4- $\mathrm{diOCH}_{3}$ & $2-\mathrm{NO}_{2}$ & $6.36 \pm 0.12$ & Anace $^{a}$ & & & $0.04 \pm 0.01$ \\
\hline
\end{tabular}

\subsection{In Vitro Metabolic Stability Study}

Based on the result of the in vitro CETP inhibitory assay, potent inhibitors 30 and 32 were selected for the in vitro metabolic stability study. As shown in Table 3, compound 30 showed weak stability, with a clearance rate of 48.1 and $121.7 \mu \mathrm{L} / \mathrm{min} / \mathrm{mg}$ in human and rat liver microsomes, while compound 32 exhibited acceptable stability, with a clearance rate of 29.8 and $79.3 \mu \mathrm{L} / \mathrm{min} / \mathrm{mg}$ in human and rat liver microsomes.

Table 3. In vitro metabolic stability study of 30,32 .

\begin{tabular}{ccccccc}
\hline \multirow{2}{*}{ Compound } & \multicolumn{5}{c}{ Human Liver Microsome Rat Liver Microsome } \\
\cline { 2 - 7 } & $\begin{array}{c}\mathbf{C L}^{\mathbf{a}} \\
(\mu \mathrm{L} / \mathbf{m i n} / \mathbf{m g})\end{array}$ & $\begin{array}{c}\text { Remaining } \\
(\mathbf{T}=\mathbf{6 0} \mathbf{m i n})\end{array}$ & $\begin{array}{c}\text { Remaining } \\
(\mathbf{N C F}=\mathbf{6 0} \mathbf{m i n})\end{array}$ & $\begin{array}{c}\mathbf{b} \mathbf{b}^{\mathbf{b}} \\
(\mu \mathrm{L} / \mathbf{m i n} / \mathbf{m g})\end{array}$ & $\begin{array}{c}\text { Remaining } \\
(\mathbf{T}=\mathbf{6 0} \mathbf{m i n})\end{array}$ & $\begin{array}{c}\text { Remaining } \\
(\mathbf{N C F}=\mathbf{6 0} \mathbf{m i n})\end{array}$ \\
\hline 30 & 48.1 & $22.9 \%$ & $68.0 \%$ & 121.7 & $3.2 \%$ & $90.5 \%$ \\
32 & 29.8 & $39.3 \%$ & $69.1 \%$ & 79.3 & $10.1 \%$ & $101.3 \%$ \\
\hline
\end{tabular}

${ }^{a}$ Clearance rate, $\mathrm{CL}<100 \mu \mathrm{L} / \mathrm{min} / \mathrm{mg}$ means acceptable stability; ${ }^{\mathrm{b}}$ The abbreviation of no co-factor. No NADPH (nicotinamide adenine dinucleotide phosphate) regenerating system is added into NCF (no co-factor) sample (replaced by buffer) during the 60 min incubation.

\section{Experimental}

\subsection{Chemicals and Instruments}

All chemicals and reagents were obtained from commercial sources and were used without purification. TLC, performed on silica gel plates (Indicator F-254), was used to monitor the reactions. Column chromatography, performed on silica gel (200 to 300 mesh) was utilized to purify the compounds. The melting points (uncorrected) were determined on a Buchi 353 melting-point apparatus. The purities of the target compounds were detected by HPLC, performed on a Waters 1525-2489 (Waters, Milford, MA, USA), with a chromatographic column (Kromasil, C-18, $5 \mu \mathrm{m}$, $150 \mathrm{~mm} \times 4.6 \mathrm{~mm}$ ), at $\geq 95 \%$. The method conditions were as follows: a mixture of solvents $\mathrm{H}_{2} \mathrm{O}(\mathrm{A})$ and $\mathrm{CH}_{3} \mathrm{CN}$ (B) $(\mathrm{VA}: \mathrm{VB}=5: 95)$ as eluent and a flow rate of $1.0 \mathrm{~mL} / \mathrm{min}$. Peaks were detected at $\lambda=254 \mathrm{~nm}$. NMR spectra were collected on Bruker (Billerica, MA, USA) $400 \mathrm{MHz}$ and $600 \mathrm{MHz}$ instruments, using tetramethylchlorosilane as an internal standard and $\mathrm{CDCl}_{3}$ or DMSO- $d_{6}$ as solvent. ESI-HRMS spectra were obtained on a Bruker Micromass time of flight mass spectrometer.

\subsection{Synthesis}

2-Chloro-N-(2-oxo-2-phenylethyl)acetamide (7). 2-amino-1-phenylethan-1-one hydrochloride 6 (0.50 g, $2.9 \mathrm{mmol})$ was dissolved in dichloromethane $(10 \mathrm{~mL})$, and triethylamine $(13 \mathrm{~mL}, 8.9 \mathrm{mmol})$ was added. The mixture was cooled, and 2-chloroacetyl chloride $(0.45 \mathrm{~g}, 4.0 \mathrm{mmol})$ was added in drops at $0{ }^{\circ} \mathrm{C}$. After $2 \mathrm{~h}$, the solution was recovered to room temperature for $16 \mathrm{~h}$. Then the mixture was poured into water $(20 \mathrm{~mL})$ and extracted with dichloromethane $(10 \mathrm{~mL} \times 3)$, and the combined organic layers were washed with water $(10 \mathrm{~mL} \times 3)$ and brine $(10 \mathrm{~mL} \times 3)$, dried over $\mathrm{Na}_{2} \mathrm{SO}_{4}$, and concentrated in vacuo. 
The residue was purified by chromatography on silica gel (petroleum ether:ethyl acetate $=4: 1$ ) to give $7(0.39 \mathrm{~g}, 62.9 \%)$ as a white solid.

2-(Chloromethyl)-5-phenyloxazole (13a). Intermediate 7 (0.20 g, $1 \mathrm{mmol})$ was dissolved in acetonitrile $(10 \mathrm{~mL})$, and phosphorus oxychloride $(0.17 \mathrm{~mL}, 1.9 \mathrm{mmol})$ was added in a slow stream. The solution was heated at reflux for $4 \mathrm{~h}$ and then cooled to room temperature and concentrated. Ethyl acetate $(20 \mathrm{~mL})$ was added, washed with water and brine, dried over $\mathrm{Na}_{2} \mathrm{SO}_{4}$, and concentrated in vacuo. The residue was purified by chromatography on silica gel (petroleum ether:ethyl acetate $=20: 1$ ) to give 13a $(0.13 \mathrm{~g}, 66.2 \%)$ as a white solid.

2-(Chloromethyl)-5-phenylthiazole (13b). Intermediate $7(0.30 \mathrm{~g}, 1.4 \mathrm{mmol})$ was dissolved in tetrahydrofuran $(5 \mathrm{~mL})$, and Lawesson's reagent $(0.34 \mathrm{~g}, 0.80 \mathrm{mmol})$ was added. The solution was heated at reflux for $4 \mathrm{~h}$ and then cooled to room temperature. The solvent was removed under reduced pressure, and the resulting residue was dissolved in ethyl acetate. The solution was washed with water and brine, dried over $\mathrm{Na}_{2} \mathrm{SO}_{4}$, and concentrated in vacuo. The residue was purified by chromatography on silica gel (petroleum ether:ethyl acetate $=10: 1)$ to give $\mathbf{1 3 b}(0.10 \mathrm{~g}, 59.6 \%)$ as a white solid.

Ethyl 5-Methyl-1-phenyl-1H-pyrazole-3-carboxylate (9). Phenylhydrazine (0.50 g, $5.0 \mathrm{mmol})$ and ethyl acetopyruvate $(1.1 \mathrm{~g}, 7.0 \mathrm{mmol})$ were dissolved in ethanol $(10 \mathrm{~mL})$. After being heated at reflux for $2 \mathrm{~h}$, the reaction mixture was cooled to room temperature and concentrated in vacuo. The residue was dissolved in ethyl acetate, washed with water and brine, dried over $\mathrm{Na}_{2} \mathrm{SO}_{4}$, and concentrated in vacuo. The residue was purified by chromatography on silica gel (petroleum ether:ethyl acetate $=10: 1$ ) to give $9(0.50 \mathrm{~g}, 43.6 \%)$ as a white solid.

3-(Chloromethyl)-5-methyl-1-phenyl-1H-pyrazole (13c). In a solution of intermediate 9 (92.1 mg, $0.40 \mathrm{mmol})$ dissolved in ethanol $(5 \mathrm{~mL})$, sodium borohydride $(19.0 \mathrm{mg}, 0.50 \mathrm{mmol})$ was added. The mixture was stirred at room temperature for $30 \mathrm{~min}$, and then water was added. The solution was extracted with ethyl acetate, and the combined organic layers were washed with water and brine, dried over $\mathrm{Na}_{2} \mathrm{SO}_{4}$, and concentrated in vacuo. The residue was dissolved in DMF $(2 \mathrm{~mL})$; then thionyl chloride $(0.10 \mathrm{~mL}, 1.4 \mathrm{mmol})$ was added. After reflux for $1 \mathrm{~h}$, water was added and extracted with ethyl acetate. The combined organic layers were washed with water and brine, dried over $\mathrm{Na}_{2} \mathrm{SO}_{4}$, and concentrated in vacuo. The residue was purified by chromatography on silica gel (petroleum ether:ethyl acetate $=10: 1)$ to give $13 \mathrm{c}(66.6 \mathrm{mg}, 80.5 \%)$ as a white solid.

Ethyl 4-Phenylthiazole-2-carboxylate (11). A mixture of 2-bromo-1-phenylethan-1-one (0.50 g, $2.5 \mathrm{mmol})$ and ethyl 2-amino-2-thioxoacetate $(0.50 \mathrm{~g}, 3.8 \mathrm{mmol})$ was dissolved in ethanol $(10 \mathrm{~mL})$. The solution was heated at reflux for $6 \mathrm{~h}$ and then cooled to room temperature. After being concentrated, the residue was dissolved in ethyl acetate $(20 \mathrm{~mL})$; then the solution was washed with water and brine, dried over $\mathrm{Na}_{2} \mathrm{SO}_{4}$, and concentrated in vacuo. The residue was purified by chromatography on silica gel (petroleum ether:ethyl acetate $=20: 1)$ to give $\mathbf{1 1}(0.43 \mathrm{~g}, 73.6 \%)$ as a white solid.

2-(Chloromethyl)-4-phenylthiazole (13d). The ester function in $\mathbf{1 1}$ was reduced with $\mathrm{NaBH}_{4}$ and reacted subsequently with $\mathrm{SOCl}_{2}$ to afford $\mathbf{1 3 d}$, and this operation was the same as the step in the synthetic intermediate 13c. Compound 13d was obtained as a white solid. Yield: 75.9\%.

2-(Chloromethyl)-5-phenyl-1,3,4-oxadiazole (13e). A mixture of benzohydrazide (0.50 g, $3.7 \mathrm{mmol})$, 2-chloroacetic acid $(0.35 \mathrm{~g}, 3.7 \mathrm{mmol})$, and phosphorus oxychloride $(1.0 \mathrm{~mL}, 11.0 \mathrm{mmol})$ was added to a three-necked round bottom flask. The solution was heated at reflux for $6 \mathrm{~h}$ and then cooled to $0{ }^{\circ} \mathrm{C}$ and neutralized to $\mathrm{pH} 9$ with a saturated sodium carbonate aqueous solution. The precipitate was filtered, washed with water, and dried under an infrared lamp. Compound 13e $(0.58 \mathrm{~g}, 81.1 \%)$ was obtained as a white solid.

2-(Chloromethyl)-1H-benzo[d]imidazole (13f). A mixture of benzene-1,2-diamine ( $2.0 \mathrm{~g}, 18.0 \mathrm{mmol})$ and ethyl 2-chloroacetate, $(2.6 \mathrm{~mL}, 24.0 \mathrm{mmol})$ was dissolved in dilute hydrochloric acid solution 
$(4 \mathrm{~mol} / \mathrm{L}, 16 \mathrm{~mL})$. The solution was heated at $110^{\circ} \mathrm{C}$ for $4 \mathrm{~h}$ and then cooled to room temperature. The reaction solution was poured into ice water and then neutralized to $\mathrm{pH} 9$ with ammonium hydroxide. The precipitate was filtered, washed with water, and dried under an infrared lamp to obtain compound $\mathbf{1 3 f}(2.7 \mathrm{~g}, 91.3 \%)$ was obtained as a white solid.

2-(Chloromethyl)benzo[d]oxazole $(\mathbf{1 3 g})$. In a solution of 2-aminophenol $(0.50 \mathrm{~g}, 4.6 \mathrm{mmol})$ dissolved in chlorobenzene $(5 \mathrm{~mL}), 2$-chloroacetyl chloride $(0.52 \mathrm{~g}, 4.6 \mathrm{mmol})$ and pyridine $(0.02 \mathrm{~mL})$ were added. The mixture was stirred at room temperature for $2 \mathrm{~h}$; then $p$-toluene sulfonic acid $(0.08 \mathrm{~g}, 0.46 \mathrm{mmol})$ was added. The mixture was heated at reflux for $8 \mathrm{~h}$ and then cooled to room temperature. The solvent was removed under reduced pressure, and the resulting residue was dissolved in ethyl acetate $(30 \mathrm{~mL})$. The solution was washed with water and brine, dried over $\mathrm{Na}_{2} \mathrm{SO}_{4}$, and concentrated in vacuo. The residue was purified by chromatography on silica gel (petroleum ether:ethyl acetate $=10: 1$ ) to give $13 \mathrm{~g}(0.70 \mathrm{~g}, 90.2 \%)$ as a yellow oil.

3-Phenoxy-N-((5-phenyloxazol-2-yl)methyl)aniline (16a). A mixture of 3-phenoxyaniline $(0.20 \mathrm{~g}, 18.0 \mathrm{mmol})$ and 13a $(0.20 \mathrm{~g}, 18.0 \mathrm{mmol})$ was dissolved in DMF $(10 \mathrm{~mL})$, followed by the addition of potassium carbonate $(0.90 \mathrm{~g}, 6.48 \mathrm{mmol})$ and KI. The solution was stirred at room temperature for $12 \mathrm{~h}$ and then poured into water and extracted with ethyl acetate. The combined organic layers were washed with water and brine, dried over $\mathrm{Na}_{2} \mathrm{SO}_{4}$, and concentrated in vacuo. The residue was purified by chromatography on silica gel (petroleum ether:ethyl acetate $=4: 1)$ to give $16 \mathbf{a}(0.26 \mathrm{~g}, 70.3 \%)$ as a colourless oil.

N-(4-Fluorobenzyl)-3-phenoxy-N-((5-phenyloxazol-2-yl)methyl)aniline (17a). Compound 16a (0.20 g, $0.60 \mathrm{mmol})$ was added to a solution of (Bromomethyl)-4-fluorobenzene $(0.08 \mathrm{~mL}, 0.60 \mathrm{mmol})$ in DMF $(5 \mathrm{~mL})$, followed by the addition of potassium carbonate $(0.50 \mathrm{~g}, 3.6 \mathrm{mmol})$ and KI. The solution was stirred at room temperature for $24 \mathrm{~h}$ and then poured into water and extracted with ethyl acetate. The combined organic layers were washed with water and brine, dried over $\mathrm{Na}_{2} \mathrm{SO}_{4}$, and concentrated in vacuo. The residue was purified by chromatography on silica gel (petroleum ether:ethyl acetate $=4: 1$ ) to give 17a $(0.18 \mathrm{~g}, 66.9 \%)$ as a yellow solid. m.p. $81.0-82.4{ }^{\circ} \mathrm{C}$. ${ }^{1} \mathrm{H}-\mathrm{NMR}\left(400 \mathrm{MHz}, \mathrm{DMSO}-d_{6}\right)$ $\delta: 7.65 \sim 7.60(\mathrm{~m}, 3 \mathrm{H}), 7.46(\mathrm{t}, J=7.6 \mathrm{~Hz}, 2 \mathrm{H}), 7.38 \sim 7.27(\mathrm{~m}, 5 \mathrm{H}), 7.18 \sim 7.11(\mathrm{~m}, 3 \mathrm{H}), 7.06(\mathrm{t}, J=7.4 \mathrm{~Hz}, 1 \mathrm{H})$, $6.90(\mathrm{~d}, J=7.7 \mathrm{~Hz}, 2 \mathrm{H}), 6.61(\mathrm{dd}, J=8.3,2.2 \mathrm{~Hz}, 1 \mathrm{H}), 6.46(\mathrm{t}, J=2.2 \mathrm{~Hz}, 1 \mathrm{H}), 6.26(\mathrm{dd}, J=7.9,1.8 \mathrm{~Hz}, 1 \mathrm{H})$, $4.84(\mathrm{~s}, 2 \mathrm{H}), 4.72$ (s, 2H). ${ }^{13} \mathrm{C}-\mathrm{NMR}\left(150 \mathrm{MHz}, \mathrm{DMSO}-d_{6}\right) \delta: 161.65(\mathrm{~d}, J=240 \mathrm{~Hz}), 161.50,157.82,157.03$, $151.18,149.93,135.13,135.11,130.67(\times 2), 130.26(\times 2), 129.55,129.02,128.97,127.87,124.26(\times 2), 123.52$, $122.98,118.77(\times 2), 115.75,115.61,108.70,107.51,104.09,54.71,48.70$. HRMS calcd. for $\mathrm{C}_{29} \mathrm{H}_{23} \mathrm{FN}_{2} \mathrm{O}_{2}$ ， $[\mathrm{M}+\mathrm{Na}]^{+}, 473.1641$; found 473.1684. HPLC: $t_{\mathrm{R}}=11.84 \mathrm{~min}, 97.50 \%$.

N-(4-Fluorobenzyl)-3-phenoxy-N-((5-phenylthiazol-2-yl)methyl)aniline (17b). Yellow solid, yield: 84.0\%. m.p. 90.5-92.5 ${ }^{\circ} \mathrm{C} .{ }^{1} \mathrm{H}-\mathrm{NMR}\left(400 \mathrm{MHz}, \mathrm{DMSO}-d_{6}\right) \delta: 8.13(\mathrm{~s}, 1 \mathrm{H}), 7.65 \sim 7.60(\mathrm{~m}, 2 \mathrm{H}), 7.43(\mathrm{t}, J=7.5 \mathrm{~Hz}$, 2H), 7.37 7.26 (m, 5H), 7.19 7.11 (m, 3H), $7.07(\mathrm{t}, J=7.4 \mathrm{~Hz}, 1 \mathrm{H}), 6.91 \sim 6.86(\mathrm{~m}, 2 \mathrm{H}), 6.59(\mathrm{dd}, J=8.4$, $2.2 \mathrm{~Hz}, 1 \mathrm{H}), 6.41(\mathrm{t}, J=2.2 \mathrm{~Hz}, 1 \mathrm{H}), 6.27(\mathrm{dd}, J=7.9,1.9 \mathrm{~Hz}, 1 \mathrm{H}), 4.96(\mathrm{~s}, 2 \mathrm{H}), 4.74(\mathrm{~s}, 2 \mathrm{H})$. ${ }^{13} \mathrm{C}-\mathrm{NMR}\left(150 \mathrm{MHz}, \mathrm{DMSO}-d_{6}\right) \delta: 169.45,161.69(\mathrm{~d}, J=240 \mathrm{~Hz}), 157.88,156.93,149.50,138.98,138.90$, $134.92,131.32,130.77,130.25(\times 2), 129.73(\times 2), 129.18,129.13,128.76,126.76(\times 2), 123.57,118.84(\times 2)$, $115.82,115.68,108.94,107.62,104.32,54.47,53.54$. HRMS calcd. for $\mathrm{C}_{29} \mathrm{H}_{23} \mathrm{FN}_{2} \mathrm{OS},[\mathrm{M}+\mathrm{Na}]^{+}, 489.1413$; found 489.1462. HPLC: $t_{\mathrm{R}}=16.10 \mathrm{~min}, 95.77 \%$.

N-(4-Fluorobenzyl)-N-((5-methyl-1-phenyl-1H-pyrazol-3-yl)methyl)-3-phenoxyaniline (17c). Yellow oil, yield: 64.9\%. ${ }^{1} \mathrm{H}-\mathrm{NMR}\left(400 \mathrm{MHz}, \mathrm{DMSO}-d_{6}\right) \delta: 7.49 \sim 7.43(\mathrm{~m}, 4 \mathrm{H}), 7.41 \sim 7.36(\mathrm{~m}, 1 \mathrm{H}), 7.34 \sim 7.29(\mathrm{~m}, 2 \mathrm{H})$, $7.19 \sim 7.15(\mathrm{~m}, 2 \mathrm{H}), 7.12 \sim 7.06(\mathrm{~m}, 4 \mathrm{H}), 6.90 \sim 6.86(\mathrm{~m}, 2 \mathrm{H}), 6.43 \sim 6.39(\mathrm{~m}, 1 \mathrm{H}), 6.24 \sim 6.20(\mathrm{~m}, 2 \mathrm{H})$, $6.00(\mathrm{~s}, 1 \mathrm{H}), 4.69(\mathrm{~s}, 2 \mathrm{H}), 4.51(\mathrm{~s}, 2 \mathrm{H}), 2.18(\mathrm{~s}, 3 \mathrm{H}) .{ }^{13} \mathrm{C}-\mathrm{NMR}\left(150 \mathrm{MHz}, \mathrm{DMSO}-d_{6}\right) \delta: 160.96$ $(\mathrm{d}, J=240 \mathrm{~Hz}), 157.16,156.37,149.08,147.95,140.64,139.21,134.39,130.02,129.64(\times 2), 128.99(\times 2)$, $128.27,128.22,127.27,124.17(\times 2), 122.90,118.14(\times 2), 115.13,114.99,107.92,106.47,106.02$, 103.20, 53.23, 47.01, 13.15. HRMS calcd. for $\mathrm{C}_{30} \mathrm{H}_{26} \mathrm{FN}_{3} \mathrm{O},[\mathrm{M}+\mathrm{H}]^{+}, 464.2138$; found 464.2176. HPLC: $t_{\mathrm{R}}=10.74 \mathrm{~min}, 97.05 \%$. 
N-(4-Fluorobenzyl)-3-phenoxy-N-((4-phenylthiazol-2-yl)methyl)aniline (17d). Colourless oil, yield: 70.3\%. ${ }^{1} \mathrm{H}-\mathrm{NMR}\left(400 \mathrm{MHz}\right.$, DMSO- $\left.d_{6}\right) \delta: 8.02(\mathrm{~s}, 1 \mathrm{H}), 7.95 \sim 7.91(\mathrm{~m}, 2 \mathrm{H}), 7.44(\mathrm{t}, J=7.5 \mathrm{~Hz}, 2 \mathrm{H})$, 7.37 7.31 (m, 3H), 7.29 7.25 (m, 2H), 7.19 7.11 (m, 3H), $7.03(\mathrm{t}, J=7.4 \mathrm{~Hz}, 1 \mathrm{H}), 6.90 \sim 6.86(\mathrm{~m}, 2 \mathrm{H})$, $6.58(\mathrm{dd}, J=8.3,2.2 \mathrm{~Hz}, 1 \mathrm{H}), 6.42(\mathrm{t}, J=2.2 \mathrm{~Hz}, 1 \mathrm{H}), 6.26(\mathrm{dd}, J=8.0,2.0 \mathrm{~Hz}, 1 \mathrm{H}), 5.02(\mathrm{~s}, 2 \mathrm{H}), 4.75(\mathrm{~s}, 2 \mathrm{H})$. ${ }^{13} \mathrm{C}-\mathrm{NMR}\left(150 \mathrm{MHz}\right.$, DMSO- $\left.d_{6}\right) \delta: 170.52,161.68(\mathrm{~d}, J=241 \mathrm{~Hz}), 157.88,156.91,154.70,149.51,134.97$, $134.95,134.54,130.75,130.25(\times 2), 129.25(\times 2), 129.21,129.16,128.47,126.42(\times 2), 123.55,118.81(\times 2)$, $115.80,115.65,114.58,108.90,107.62,104.27,54.49,53.63$. HRMS calcd. for $\mathrm{C}_{29} \mathrm{H}_{23} \mathrm{FN}_{2} \mathrm{OS}$, $\left[\mathrm{M}+\mathrm{Na}^{+}\right.$, 489.1413; found 489.1467 . HPLC: $t_{\mathrm{R}}=17.55 \mathrm{~min}, 98.71 \%$.

N-(4-Fluorobenzyl)-3-phenoxy-N-((5-phenyl-1,3,4-oxadiazol-2-yl)methyl)aniline (17e). White solid, yield: 64.9\%. m.p. $97.3-98.2{ }^{\circ} \mathrm{C} .{ }^{1} \mathrm{H}-\mathrm{NMR}\left(400 \mathrm{MHz}, \mathrm{CDCl}_{3}\right) \delta: 7.99(\mathrm{~d}, J=7.0 \mathrm{~Hz}, 2 \mathrm{H}), 7.58 \sim 7.48(\mathrm{~m}, 3 \mathrm{H})$, $7.32 \sim 7.26(\mathrm{~m}, 4 \mathrm{H}), 7.21(\mathrm{t}, J=8.2 \mathrm{~Hz}, 1 \mathrm{H}), 7.11 \sim 6.97(\mathrm{~m}, 5 \mathrm{H}), 6.71(\mathrm{dd}, J=8.3,2.0 \mathrm{~Hz}, 1 \mathrm{H}), 6.60(\mathrm{~s}, 1 \mathrm{H})$, $6.47(\mathrm{~d}, J=8.0 \mathrm{~Hz}, 1 \mathrm{H}), 4.78(\mathrm{~s}, 2 \mathrm{H}), 4.67(\mathrm{~s}, 2 \mathrm{H}) .{ }^{13} \mathrm{C}-\mathrm{NMR}\left(150 \mathrm{MHz}, \mathrm{DMSO}-d_{6}\right) \delta: 164.72,164.67,161.68$ $(\mathrm{d}, J=241 \mathrm{~Hz}), 157.88,157.03,149.70,134.90,134.88,132.53,130.77,130.27(\times 2), 129.93,129.07,129.01$, 126.91(×2), 123.68, 123.56, 118.78(×2), 115.78, 115.64, 108.88, 107.87, 104.33, 54.49, 49.07. HRMS calcd. for $\mathrm{C}_{28} \mathrm{H}_{22} \mathrm{FN}_{3} \mathrm{O}_{2}$, $[\mathrm{M}+\mathrm{Na}]^{+}$, 474.1594; found 474.1638. HPLC: $t_{\mathrm{R}}=8.75 \mathrm{~min}, 96.33 \%$.

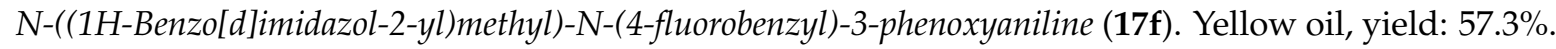
${ }^{1} \mathrm{H}-\mathrm{NMR}\left(600 \mathrm{MHz}, \mathrm{DMSO}-d_{6}\right) \delta: 7.65 \sim 7.60(\mathrm{~m}, 1 \mathrm{H}), 7.42 \sim 7.39(\mathrm{~m}, 1 \mathrm{H}), 7.31(\mathrm{t}, J=7.9 \mathrm{~Hz}, 2 \mathrm{H})$, $7.20 \sim 7.15(\mathrm{~m}, 4 \mathrm{H}), 7.12 \sim 7.06(\mathrm{~m}, 3 \mathrm{H}), 7.04(\mathrm{t}, J=8.1 \mathrm{~Hz}, 1 \mathrm{H}), 6.93(\mathrm{~d}, J=7.8 \mathrm{~Hz}, 2 \mathrm{H}), 6.52 \sim 6.45(\mathrm{~m}, 2 \mathrm{H})$, $6.36(\mathrm{t}, J=2.1 \mathrm{~Hz}, 1 \mathrm{H}), 6.16(\mathrm{dd}, J=7.9,2.0 \mathrm{~Hz}, 1 \mathrm{H}), 5.55(\mathrm{~s}, 2 \mathrm{H}), 4.52(\mathrm{~d}, J=5.1 \mathrm{~Hz}, 2 \mathrm{H})$. ${ }^{13} \mathrm{C}-\mathrm{NMR}\left(150 \mathrm{MHz}, \mathrm{DMSO}-d_{6}\right) \delta: 161.90(\mathrm{~d}, J=241 \mathrm{~Hz}), 157.88,157.29,152.73,150.39,142.43$, $135.93,133.48,130.52,130.26(\times 2), 129.34,129.28,123.44,122.81,122.16,119.42,118.83(\times 2), 115.97$, $115.83,110.90,108.31,106.99,103.35,46.16,41.14$. HRMS calcd. for $\mathrm{C}_{27} \mathrm{H}_{22} \mathrm{FN}_{3} \mathrm{O}$, $[\mathrm{M}+\mathrm{H}]^{+}, 424.1825$; found 424.1859 . HPLC: $t_{R}=5.72 \mathrm{~min}, 97.98 \%$.

$\mathrm{N}$-(Benzo[d]oxazol-2-ylmethyl)-N-(4-fluorobenzyl)-3-phenoxyaniline (17g). Colourless oil, yield: 71.0\%. ${ }^{1} \mathrm{H}-\mathrm{NMR}\left(400 \mathrm{MHz}\right.$, DMSO- $\left.d_{6}\right) \delta: 7.74 \sim 7.67(\mathrm{~m}, 2 \mathrm{H}), 7.40 \sim 7.32(\mathrm{~m}, 4 \mathrm{H}), 7.27 \sim 7.21(\mathrm{~m}, 2 \mathrm{H})$, $7.17 \sim 7.03(\mathrm{~m}, 4 \mathrm{H}), 6.89 \sim 6.85(\mathrm{~m}, 2 \mathrm{H}), 6.58(\mathrm{dd}, J=8.3,2.2 \mathrm{~Hz}, 1 \mathrm{H}), 6.41(\mathrm{t}, J=2.2 \mathrm{~Hz}, 1 \mathrm{H}), 6.24(\mathrm{dd}, J=8.0$, $1.9 \mathrm{~Hz}, 1 \mathrm{H}), 5.01(\mathrm{~s}, 2 \mathrm{H}), 4.76(\mathrm{~s}, 2 \mathrm{H}) .{ }^{13} \mathrm{C}-\mathrm{NMR}\left(150 \mathrm{MHz}, \mathrm{DMSO}-d_{6}\right) \delta: 164.45,161.66(\mathrm{~d}, J=241 \mathrm{~Hz})$, $157.89,156.89,150.76,149.81,141.04,135.06,130.72,130.21(\times 2), 128.95,128.90,125.59,124.96,123.56$, 120.10, 118.83(×2), 115.78, 115.64, 111.28, 108.50, 107.39, 103.89, 54.81, 48.96. HRMS calcd. for $\mathrm{C}_{27} \mathrm{H}_{21} \mathrm{FN}_{2} \mathrm{O}_{2},[\mathrm{M}+\mathrm{H}]^{+}$, 425.1665; found 425.1725. HPLC: $t_{\mathrm{R}}=18.55 \mathrm{~min}, 96.41 \%$.

\subsection{General Procedure for the Synthesis of Compounds 21-49}

A mixture of substituted 2-bromo-1-phenylethan-1-one $(2.5 \mathrm{mmol})$ and ethyl 2-amino2-thioxoacetate $(3.8 \mathrm{mmol})$ was dissolved in ethanol $(10 \mathrm{~mL})$. The solution was heated at reflux for $6 \mathrm{~h}$ and then cooled to room temperature. After being concentrated, the residue was dissolved in ethyl acetate $(20 \mathrm{~mL})$; then the solution was washed with water and brine, dried over $\mathrm{Na}_{2} \mathrm{SO}_{4}$, and concentrated in vacuo. The residue was purified by chromatography on silica gel to give $\mathbf{1 8}$. The intermediate 19 was obtained by an operation similar to that described for the preparation of $13 \mathrm{c}$. Subsequently, substituted arylamine reacted with 19 according to the synthesis condition of compound 16a to produce 20. Finally, target compounds 21 to 49 were prepared according to the procedure for 17a, except that different substrates were used.

N-(4-Fluorobenzyl)-3-methoxy-N-((4-phenylthiazol-2-yl)methyl)aniline (21). Colourless oil, yield: 64.1\%. ${ }^{1} \mathrm{H}-\mathrm{NMR}\left(400 \mathrm{MHz}, \mathrm{DMSO}-d_{6}\right) \delta: 8.00(\mathrm{~s}, 1 \mathrm{H}), 7.98 \sim 7.94(\mathrm{~m}, 2 \mathrm{H}), 7.45(\mathrm{t}, J=7.6 \mathrm{~Hz}, 2 \mathrm{H})$, $7.39 \sim 7.32(\mathrm{~m}, 3 \mathrm{H}), 7.17(\mathrm{t}, J=12.3 \mathrm{~Hz}, 2 \mathrm{H}), 7.04(\mathrm{t}, J=8.2 \mathrm{~Hz}, 1 \mathrm{H}), 6.39(\mathrm{dd}, J=8.3,2.2 \mathrm{~Hz}, 1 \mathrm{H})$, $6.31(\mathrm{t}, J=2.2 \mathrm{~Hz}, 1 \mathrm{H}), 6.27(\mathrm{dd}, J=8.1,2.1 \mathrm{~Hz}, 1 \mathrm{H}), 5.01(\mathrm{~s}, 2 \mathrm{H}), 4.76(\mathrm{~s}, 2 \mathrm{H}), 3.62(\mathrm{~s}, 3 \mathrm{H})$. ${ }^{13} \mathrm{C}-\mathrm{NMR}\left(150 \mathrm{MHz}, \mathrm{DMSO}-d_{6}\right) \delta: 171.03,162.47 \sim 160.87(\mathrm{~d}, J=240 \mathrm{~Hz}), 160.66,154.60,149.19$, 135.30, 134.56, 130.30, 129.28(×3), 129.22, 128.47, 126.40(×2), 115.76, 115.62, 114.61, 106.54, 102.82, 
100.12, 55.18, 54.44, 53.62. HRMS calcd. for $\mathrm{C}_{24} \mathrm{H}_{21} \mathrm{FN}_{2} \mathrm{OS}$, $[\mathrm{M}+\mathrm{H}]^{+}, 405.1437$; found 405.1480 . HPLC: $t_{\mathrm{R}}=8.71 \mathrm{~min}, 95.81 \%$.

$N$-(4-Fluorobenzyl)-3,4-dimethoxy-N-((4-phenylthiazol-2-yl)methyl)aniline (22). Colourless oil, yield: 65.6\%. ${ }^{1} \mathrm{H}-\mathrm{NMR}\left(600 \mathrm{MHz}\right.$, DMSO- $\left.d_{6}\right) \delta: 7.99(\mathrm{~s}, 1 \mathrm{H}), 7.96 \sim 7.92(\mathrm{~m}, 2 \mathrm{H}), 7.44(\mathrm{t}, J=7.7 \mathrm{~Hz}, 2 \mathrm{H})$, $7.40 \sim 7.36(\mathrm{~m}, 2 \mathrm{H}), 7.34(\mathrm{t}, J=7.4 \mathrm{~Hz}, 1 \mathrm{H}), 7.16(\mathrm{t}, J=8.9 \mathrm{~Hz}, 2 \mathrm{H}), 6.74(\mathrm{~d}, J=8.8 \mathrm{~Hz}, 1 \mathrm{H})$, $6.56(\mathrm{~d}, J=2.8 \mathrm{~Hz}, 1 \mathrm{H}), 6.27(\mathrm{dd}, J=8.8,2.8 \mathrm{~Hz}, 1 \mathrm{H}), 4.90(\mathrm{~s}, 2 \mathrm{H}), 4.65(\mathrm{~s}, 2 \mathrm{H}), 3.62(\mathrm{~d}, J=6.6 \mathrm{~Hz}$, $6 \mathrm{H}) .{ }^{13} \mathrm{C}-\mathrm{NMR}\left(150 \mathrm{MHz}, \mathrm{DMSO}-d_{6}\right) \delta: 171.25,161.67$ (d, $\left.J=240 \mathrm{~Hz}\right), 154.40,149.86,142.94,142.04$, $135.47,134.59,130.06,129.69,129.28(\times 2), 129.45,126.37(\times 2), 115.67,115.53,114.67,113.96,106.28$, 101.19, 56.54, 55.79, 55.27, 54.19. HRMS calcd. for $\mathrm{C}_{25} \mathrm{H}_{23} \mathrm{FN}_{2} \mathrm{O}_{2} \mathrm{~S}$, [M + Na] ${ }^{+}, 457.1362$; found 457.1409. HPLC: $t_{\mathrm{R}}=7.11 \mathrm{~min}, 98.24 \%$.

$\mathrm{N}$-(4-Fluorobenzyl)-N-((4-(4-nitrophenyl)thiazol-2-yl)methyl)-3-(trifluoromethoxy)aniline (23). Colourless oil, yield: $54.9 \% .{ }^{1} \mathrm{H}-\mathrm{NMR}\left(600 \mathrm{MHz}, \mathrm{DMSO}-d_{6}\right) \delta: 8.39(\mathrm{~s}, 1 \mathrm{H}), 8.31(\mathrm{~d}, J=9.0 \mathrm{~Hz}, 2 \mathrm{H}), 8.22(\mathrm{~d}, J=9.0 \mathrm{~Hz}$, $2 \mathrm{H}), 7.40 \sim 7.35(\mathrm{~m}, 2 \mathrm{H}), 7.24(\mathrm{t}, J=8.3 \mathrm{~Hz}, 1 \mathrm{H}), 7.21 \sim 7.16(\mathrm{~m}, 2 \mathrm{H}), 6.81(\mathrm{dd}, J=8.5,2.4 \mathrm{~Hz}, 1 \mathrm{H})$, $6.72(\mathrm{~s}, 1 \mathrm{H}), 6.61(\mathrm{~d}, J=8.1 \mathrm{~Hz}, 1 \mathrm{H}), 5.11(\mathrm{~s}, 2 \mathrm{H}), 4.82(\mathrm{~s}, 2 \mathrm{H}) .{ }^{13} \mathrm{C}-\mathrm{NMR}\left(150 \mathrm{MHz}, \mathrm{DMSO}-d_{6}\right)$ $\delta: 171.07,161.76(\mathrm{~d}, J=241 \mathrm{~Hz}), 152.47,149.92,149.43,147.14,140.39,134.54,131.01,129.30,129.25$, 127.31(×2), 124.75(×2), 119.15, 115.87, 115.73, 112.34, 109.27, 105.94, 62.92, 54.30, 53.32. HRMS calcd. for $\mathrm{C}_{24} \mathrm{H}_{17} \mathrm{~F}_{4} \mathrm{~N}_{3} \mathrm{O}_{3} \mathrm{~S}$, $[\mathrm{M}+\mathrm{H}]^{+}$, 504.1005; found 504.1063. HPLC: $t_{\mathrm{R}}=12.63 \mathrm{~min}, 95.83 \%$.

$\mathrm{N}$-(4-Fluorobenzyl)-N-((4-(4-nitrophenyl)thiazol-2-yl)methyl)-3-(trifluoromethyl)aniline (24). Brown solid, yield: $65.9 \%$. m.p. $107.0-108.4{ }^{\circ} \mathrm{C} .{ }^{1} \mathrm{H}-\mathrm{NMR}\left(600 \mathrm{MHz}, \mathrm{CDCl}_{3}\right)$ 8: 8.31 8.27 (m, 2H), 8.06 8.03 $(\mathrm{m}, 2 \mathrm{H})$, $7.61(\mathrm{~s}, 1 \mathrm{H}), 7.31(\mathrm{t}, J=8.0 \mathrm{~Hz}, 1 \mathrm{H}), 7.26(\mathrm{~d}, J=7.2 \mathrm{~Hz}, 2 \mathrm{H}), 7.14(\mathrm{~s}, 1 \mathrm{H}), 7.07 \sim 7.03(\mathrm{~m}, 3 \mathrm{H})$, $6.97(\mathrm{dd}, J=8.4,2.6 \mathrm{~Hz}, 1 \mathrm{H}), 4.92(\mathrm{~s}, 2 \mathrm{H}), 4.73(\mathrm{~s}, 2 \mathrm{H}) .{ }^{13} \mathrm{C}-\mathrm{NMR}\left(150 \mathrm{MHz}, \mathrm{DMSO}-d_{6}\right) \delta:$ 170.91, $161.76(\mathrm{~d}, J=241 \mathrm{~Hz}), 152.48,148.16,147.15,140.37,134.49,130.57,129.27,129.23,127.30(\times 2)$, $125.71,124.75(\times 2), 123.91,119.19,117.13,115.91,115.77,113.85,109.41,54.26,53.21$. HRMS calcd. for $\mathrm{C}_{24} \mathrm{H}_{17} \mathrm{~F}_{4} \mathrm{~N}_{3} \mathrm{O}_{2} \mathrm{~S},[\mathrm{M}+\mathrm{H}]^{+}, 488.1056$; found 488.1104. HPLC: $t_{\mathrm{R}}=9.95 \mathrm{~min}, 96.05 \%$.

N-(4-Fluorobenzyl)-N-((4-(4-nitrophenyl)thiazol-2-yl)methyl)-[1,1'-biphenyl]-4-amine (25). Light yellow solid, yield: 54.9\%. m.p. 164.5-166.2 ${ }^{\circ} \mathrm{C} .{ }^{1} \mathrm{H}-\mathrm{NMR}\left(600 \mathrm{MHz}, \mathrm{DMSO}-d_{6}\right)$ 8: $8.38(\mathrm{~s}, 1 \mathrm{H})$, $8.34 \sim 8.30(\mathrm{~m}, 2 \mathrm{H}), 8.25 \sim 8.22(\mathrm{~m}, 2 \mathrm{H}), 7.54(\mathrm{dd}, J=8.3,1.1 \mathrm{~Hz}, 2 \mathrm{H}), 7.48(\mathrm{~d}, J=8.9 \mathrm{~Hz}, 2 \mathrm{H})$, $7.41 \sim 7.35(\mathrm{~m}, 4 \mathrm{H}), 7.23(\mathrm{dt}, J=8.5,1.1 \mathrm{~Hz}, 1 \mathrm{H}), 7.21 \sim 7.16(\mathrm{~m}, 2 \mathrm{H}), 6.88(\mathrm{~d}, J=9.0 \mathrm{~Hz}, 2 \mathrm{H}), 5.10(\mathrm{~s}, 2 \mathrm{H})$, $4.84(\mathrm{~s}, 2 \mathrm{H}) .{ }^{13} \mathrm{C}-\mathrm{NMR}\left(150 \mathrm{MHz}, \mathrm{DMSO}-d_{6}\right) \delta: 172.20,161.72(\mathrm{~d}, J=240 \mathrm{~Hz}), 152.53,147.20,147.11$, $140.48,140.39,135.08,129.59,129.29,129.24(\times 3), 127.80(\times 2), 127.33(\times 2), 126.65,126.12(\times 2), 124.77(\times 2)$, $119.07,115.85,115.70,113.94(\times 2), 54.34,54.35$. HRMS calcd. for $\mathrm{C}_{29} \mathrm{H}_{22} \mathrm{FN}_{3} \mathrm{O}_{2} \mathrm{~S},[\mathrm{M}+\mathrm{H}]^{+}, 496.1495$; found 496.1552 . HPLC: $t_{\mathrm{R}}=14.39 \mathrm{~min}, 97.20 \%$.

$\mathrm{N}$-(4-Fluorobenzyl)-N-((4-(4-nitrophenyl)thiazol-2-yl)methyl)-[1,1'-biphenyl]-3-amine (26). Light yellow solid, yield: $59.8 \%$. m.p. $149.5-150.8{ }^{\circ} \mathrm{C} .{ }^{1} \mathrm{H}-\mathrm{NMR}\left(600 \mathrm{MHz}, \mathrm{CDCl}_{3}\right) \delta: 8.27(\mathrm{~d}, J=8.8 \mathrm{~Hz}$, $2 \mathrm{H}), 8.04(\mathrm{~d}, J=8.8 \mathrm{~Hz}, 2 \mathrm{H}), 7.59(\mathrm{~s}, 1 \mathrm{H}), 7.48(\mathrm{~d}, J=7.3 \mathrm{~Hz}, 2 \mathrm{H}), 7.37(\mathrm{t}, J=7.5 \mathrm{~Hz}, 2 \mathrm{H})$, 7.32 7.27 (m, 4H), $7.10(\mathrm{~s}, 1 \mathrm{H}), 7.06 \sim 7.02(\mathrm{~m}, 3 \mathrm{H}), 6.83(\mathrm{dd}, J=8.3,2.3 \mathrm{~Hz}, 1 \mathrm{H}), 4.93(\mathrm{~s}, 2 \mathrm{H}), 4.75(\mathrm{~s}, 2 \mathrm{H})$. ${ }^{13} \mathrm{C}-\mathrm{NMR}\left(150 \mathrm{MHz}\right.$, DMSO- $\left.d_{6}\right) \delta: 172.05,161.70(\mathrm{~d}, J=240 \mathrm{~Hz}), 152.33,148.25,147.12,141.53,141.24$, $140.46,135.22,130.16,129.37,129.31,129.25(\times 2), 127.82,127.32(\times 2), 127.12(\times 2), 124.76(\times 2), 119.21$, $116.52,115.83,115.69,112.88,112.12,55.47,53.52$. HRMS calcd. for $\mathrm{C}_{29} \mathrm{H}_{22} \mathrm{FN}_{3} \mathrm{O}_{2} \mathrm{~S}$, $[\mathrm{M}+\mathrm{H}]^{+}, 496.1495$; found 496.1567. HPLC: $t_{\mathrm{R}}=13.88 \mathrm{~min}, 96.81 \%$.

$N$-(4-Fluorobenzyl)-N-((4-(4-nitrophenyl)thiazol-2-yl)methyl)-[1,1'-biphenyl]-2-amine (27). Colourless oil, yield: 50.4\%. ${ }^{1} \mathrm{H}-\mathrm{NMR}\left(600 \mathrm{MHz}, \mathrm{DMSO}-d_{6}\right) \delta: 8.31(\mathrm{~s}, 1 \mathrm{H}), 8.28(\mathrm{~d}, J=8.9 \mathrm{~Hz}, 2 \mathrm{H}), 8.17(\mathrm{~d}, J=8.9 \mathrm{~Hz}$, $2 \mathrm{H}), 7.61(\mathrm{~d}, J=7.2 \mathrm{~Hz}, 2 \mathrm{H}), 7.49(\mathrm{t}, J=7.6 \mathrm{~Hz}, 2 \mathrm{H}), 7.37(\mathrm{t}, J=7.4 \mathrm{~Hz}, 1 \mathrm{H}), 7.23 \sim 7.19(\mathrm{~m}, 2 \mathrm{H})$, 7.13 7.10 (m, 3H), 7.10 7.04 (m, 3H), $4.31(\mathrm{~s}, 2 \mathrm{H}), 4.00(\mathrm{~s}, 2 \mathrm{H}) .{ }^{13} \mathrm{C}-\mathrm{NMR}\left(150 \mathrm{MHz}\right.$, DMSO- $\left.d_{6}\right)$ $\delta: 171.99,161.71(\mathrm{~d}, J=240 \mathrm{~Hz}), 160.91,152.34,148.26,147.09,141.54,141.24,140.45,135.17,130.16$, 129.35, 129.30, 129.24(×2), 127.80, 127.29(×2), 127.11(×2), 124.72(×2), 119.17, 116.54, 115.82, 115.68, $112.88,112.13,54.48,53.51$. HRMS calcd. for $\mathrm{C}_{29} \mathrm{H}_{22} \mathrm{FN}_{3} \mathrm{O}_{2} \mathrm{~S}$, [M $\left.+\mathrm{H}\right]^{+}, 496.1495$; found 496.1563. HPLC: $t_{\mathrm{R}}=15.05 \mathrm{~min}, 95.79 \%$. 
N-(4-Fluorobenzyl)-N-((4-(4-nitrophenyl)thiazol-2-yl)methyl)-3-(thiophen-2-yl)aniline (28). Dark yellow solid, yield: $63.1 \%$. m.p. $143.9-148.8{ }^{\circ} \mathrm{C} .{ }^{1} \mathrm{H}-\mathrm{NMR}\left(600 \mathrm{MHz}, \mathrm{DMSO}-d_{6}\right) \delta: 8.38(\mathrm{~s}, 1 \mathrm{H})$, $8.32(\mathrm{~d}, J=8.7 \mathrm{~Hz}, 2 \mathrm{H}), 8.24(\mathrm{~d}, J=8.7 \mathrm{~Hz}, 2 \mathrm{H}), 7.46(\mathrm{~d}, J=5.0 \mathrm{~Hz}, 1 \mathrm{H}), 7.41(\mathrm{dd}, J=8.0,5.8 \mathrm{~Hz}$, $2 \mathrm{H}), 7.35(\mathrm{~d}, J=3.5 \mathrm{~Hz}, 1 \mathrm{H}), 7.18(\mathrm{dd}, J=16.3,8.2 \mathrm{~Hz}, 3 \mathrm{H}), 7.07(\mathrm{t}, J=4.1 \mathrm{~Hz}, 2 \mathrm{H}), 6.96(\mathrm{~d}, J=7.5 \mathrm{~Hz}$, $1 \mathrm{H}), 6.75(\mathrm{dd}, J=8.3,1.9 \mathrm{~Hz}, 1 \mathrm{H}), 5.12(\mathrm{~s}, 2 \mathrm{H}), 4.84(\mathrm{~s}, 2 \mathrm{H}) .{ }^{13} \mathrm{C}-\mathrm{NMR}\left(150 \mathrm{MHz}\right.$, DMSO- $\left.d_{6}\right) \delta: 171.84$, $161.71(\mathrm{~d}, J=240 \mathrm{~Hz}), 152.38,148.22,148.12,144.44,140.46,135.14,134.90,130.34,129.36,129.30$, $128.75,127.33(\times 2), 125.90,124.76(\times 2), 123.91,119.18,115.85,115.70,115.31,113.07,110.66,54.51,53.55$. HRMS calcd. for $\mathrm{C}_{27} \mathrm{H}_{20} \mathrm{FN}_{3} \mathrm{O}_{2} \mathrm{~S}_{2},[\mathrm{M}+\mathrm{H}]^{+}$, 502.1059; found 502.1118. HPLC: $t_{\mathrm{R}}=14.17 \mathrm{~min}, 98.03 \%$.

$N$-(4-Fluorobenzyl)-3-(1-methyl-1H-pyrazol-5-yl)-N-((4-(4-nitrophenyl)thiazol-2-yl)methyl)aniline (29) Brown solid, yield: 68.9\%. m.p. 102.2-104.5 ${ }^{\circ} \mathrm{C} .{ }^{1} \mathrm{H}-\mathrm{NMR}\left(600 \mathrm{MHz}\right.$, DMSO- $\left.d_{6}\right)$ 8: $8.38(\mathrm{~s}, 1 \mathrm{H})$, $8.32(\mathrm{~d}, J=8.9 \mathrm{~Hz}, 2 \mathrm{H}), 8.22(\mathrm{~d}, J=8.9 \mathrm{~Hz}, 2 \mathrm{H}), 7.43 \sim 7.37(\mathrm{~m}, 3 \mathrm{H}), 7.26(\mathrm{t}, J=8.0 \mathrm{~Hz}, 1 \mathrm{H})$, $7.19(\mathrm{t}, J=8.8 \mathrm{~Hz}, 2 \mathrm{H}), 6.87(\mathrm{dd}, J=8.4,2.2 \mathrm{~Hz}, 1 \mathrm{H}), 6.84(\mathrm{~s}, 1 \mathrm{H}), 6.80(\mathrm{~d}, J=7.5 \mathrm{~Hz}, 1 \mathrm{H})$, $6.24(\mathrm{~d}, J=1.8 \mathrm{~Hz}, 1 \mathrm{H}), 5.14(\mathrm{~s}, 2 \mathrm{H}), 4.85(\mathrm{~s}, 2 \mathrm{H}), 3.59(\mathrm{~s}, 3 \mathrm{H}) .{ }^{13} \mathrm{C}-\mathrm{NMR}\left(150 \mathrm{MHz}, \mathrm{DMSO}-d_{6}\right) \delta: 171.92$, $161.72(\mathrm{~d}, J=241 \mathrm{~Hz}), 152.46,148.22,147.11,143.64,140.41,138.26,134.99,131.29,130.05,129.27$, $129.22,127.29(\times 2), 124.73(\times 2), 119.09,117.99,115.84,115.70,115.04,113.58,106.05,54.48,53.64,49.08$. HRMS calcd. for $\mathrm{C}_{27} \mathrm{H}_{22} \mathrm{FN}_{5} \mathrm{O}_{2} \mathrm{~S}$, $[\mathrm{M}+\mathrm{H}]^{+}$, 500.1556; found 500.1626. HPLC: $t_{\mathrm{R}}=6.76 \mathrm{~min}, 95.89 \%$.

$\mathrm{N}$-(4-Fluorobenzyl)-3,4-dimethoxy-N-((4-(4-nitrophenyl)thiazol-2-yl)methyl)aniline (30). Light yellow solid, yield: $63.8 \%$. m.p. $111.0-112.8{ }^{\circ} \mathrm{C} .{ }^{1} \mathrm{H}-\mathrm{NMR}\left(400 \mathrm{MHz}, \mathrm{DMSO}-d_{6}\right) \delta: 8.37(\mathrm{~s}, 1 \mathrm{H}), 8.32(\mathrm{~d}, J=9.0 \mathrm{~Hz}$, $2 \mathrm{H}), 8.22(\mathrm{~d}, J=8.9 \mathrm{~Hz}, 2 \mathrm{H}), 7.39(\mathrm{dd}, J=8.4,5.7 \mathrm{~Hz}, 2 \mathrm{H}), 7.17(\mathrm{t}, J=8.8 \mathrm{~Hz}, 2 \mathrm{H}), 6.75(\mathrm{~d}, J=8.8 \mathrm{~Hz}$, $1 \mathrm{H}), 6.56(\mathrm{~d}, J=2.7 \mathrm{~Hz}, 1 \mathrm{H}), 6.28(\mathrm{dd}, J=8.8,2.7 \mathrm{~Hz}, 1 \mathrm{H}), 4.94(\mathrm{~s}, 2 \mathrm{H}), 4.66(\mathrm{~s}, 2 \mathrm{H}), 3.62(\mathrm{~d}, J=4.1 \mathrm{~Hz}$, 6H). ${ }^{13}$ C-NMR $\left(150 \mathrm{MHz}\right.$, DMSO- $\left.d_{6}\right) \delta: 163.14,162.02(\mathrm{~d}, J=241 \mathrm{~Hz}), 160.86,153.36,149.87,142.92$, 142.05, 135.47, 131.23, 129.64, 128.44, 128.38, 116.21, 116.07, 115.67(×2), 115.53, 114.48, 113.97, 106.27, 101.19, 56.55, 55.80, 55.26, 54.15. HRMS calcd. for $\mathrm{C}_{25} \mathrm{H}_{22} \mathrm{FN}_{3} \mathrm{O}_{4} \mathrm{~S}$, [M + Na $]^{+}, 502.1213$; found 502.1217. HPLC: $t_{\mathrm{R}}=7.59 \mathrm{~min}, 98.98 \%$.

N-(4-Fluorobenzyl)-N-((4-(4-fluorophenyl)thiazol-2-yl)methyl)-3,4-dimethoxyaniline (31). Light yellow oil, yield: $71.1 \%$. ${ }^{1} \mathrm{H}-\mathrm{NMR}\left(400 \mathrm{MHz}, \mathrm{DMSO}-d_{6}\right) \delta: 8.05 \sim 7.94(\mathrm{~m}, 3 \mathrm{H}), 7.38(\mathrm{~s}, 2 \mathrm{H}), 7.27(\mathrm{t}, J=7.6 \mathrm{~Hz}$, $2 \mathrm{H}), 7.16(\mathrm{t}, J=7.7 \mathrm{~Hz}, 2 \mathrm{H}), 6.74(\mathrm{~d}, J=8.1 \mathrm{~Hz}, 1 \mathrm{H}), 6.57(\mathrm{~s}, 1 \mathrm{H}), 6.28(\mathrm{~d}, J=8.4 \mathrm{~Hz}, 1 \mathrm{H}), 4.90(\mathrm{~s}, 2 \mathrm{H})$, $4.65(\mathrm{~s}, 2 \mathrm{H}), 3.63(\mathrm{~d}, J=2.7 \mathrm{~Hz}, 6 \mathrm{H}) .{ }^{13} \mathrm{C}-\mathrm{NMR}\left(150 \mathrm{MHz}, \mathrm{DMSO}-d_{6}\right) \delta: 171.42,162.33(\mathrm{~d}, J=243 \mathrm{~Hz})$, $162.47 \sim 160.86(\mathrm{~d}, J=241 \mathrm{~Hz}), 153.36,149.87,142.92,142.05,135.46,131.24,129.69,129.64,128.44,128.38$, 116.21, 116.07, 115.67, 115.53, 114.48, 113.97, 106.27, 101.19, 56.55, 55.80, 55.26, 54.15. HRMS calcd. for $\mathrm{C}_{25} \mathrm{H}_{22} \mathrm{~F}_{2} \mathrm{~N}_{2} \mathrm{O}_{2} \mathrm{~S}$, [M + Na] $]^{+}, 475.1268$; found 475.1324. HPLC: $t_{\mathrm{R}}=4.87 \mathrm{~min}, 99.31 \%$.

$\mathrm{N}$-(4-Fluorobenzyl)-3,4-dimethoxy-N-((4-(4-(trifluoromethyl)phenyl)thiazol-2-yl)methyl)aniline (32). White solid, yield: $69.9 \%$. m.p. $88.7-89.5^{\circ} \mathrm{C} .{ }^{1} \mathrm{H}-\mathrm{NMR}\left(400 \mathrm{MHz}, \mathrm{DMSO}-d_{6}\right) \delta: 8.24(\mathrm{~s}, 1 \mathrm{H}), 8.17(\mathrm{~d}, J=8.1 \mathrm{~Hz}, 2 \mathrm{H})$, $7.81(\mathrm{~d}, J=8.3 \mathrm{~Hz}, 2 \mathrm{H}), 7.39(\mathrm{dd}, J=8.5,5.7 \mathrm{~Hz}, 2 \mathrm{H}), 7.17(\mathrm{t}, J=8.9 \mathrm{~Hz}, 2 \mathrm{H}), 6.75(\mathrm{~d}, J=8.8 \mathrm{~Hz}, 1 \mathrm{H})$, $6.56(\mathrm{~d}, J=2.8 \mathrm{~Hz}, 1 \mathrm{H}), 6.28(\mathrm{dd}, J=8.8,2.8 \mathrm{~Hz}, 1 \mathrm{H}), 4.93(\mathrm{~s}, 2 \mathrm{H}), 4.66(\mathrm{~s}, 2 \mathrm{H}), 3.62(\mathrm{~d}, J=3.5 \mathrm{~Hz}, 6 \mathrm{H})$. ${ }^{13} \mathrm{C}-\mathrm{NMR}\left(150 \mathrm{MHz}\right.$, DMSO- $\left.d_{6}\right) \delta: 172.03,161.67$ (d, $\left.J=241 \mathrm{~Hz}\right), 152.76,149.88,142.87,142.11,138.26$, $135.43,135.42,129.71,129.66,128.44,126.94(\times 2), 126.28,117.36,115.67,115.53,113.94,106.34,101.24$, 56.53, 55.80, 55.30, 54.16, 49.06. HRMS calcd. for $\mathrm{C}_{26} \mathrm{H}_{22} \mathrm{~F}_{4} \mathrm{~N}_{2} \mathrm{O}_{2} \mathrm{~S}$, [M + Na] ${ }^{+}, 525.1236$; found 525.1303. HPLC: $t_{\mathrm{R}}=9.44 \mathrm{~min}, 98.71 \%$.

4-(2-(((3,4-Dimethoxyphenyl)(4-fluorobenzyl)amino)methyl)thiazol-4-yl)benzonitrile (33). Yellow solid, yield: 69.9\%. m.p. $105.4-106.6{ }^{\circ} \mathrm{C} .{ }^{1} \mathrm{H}-\mathrm{NMR}\left(600 \mathrm{MHz}, \mathrm{DMSO}-d_{6}\right) \delta: 8.28(\mathrm{~s}, 1 \mathrm{H}), 8.14(\mathrm{~d}, J=8.1 \mathrm{~Hz}$, $2 \mathrm{H}), 7.91(\mathrm{~d}, J=8.3 \mathrm{~Hz}, 2 \mathrm{H}), 7.40 \sim 7.36(\mathrm{~m}, 2 \mathrm{H}), 7.16(\mathrm{t}, J=9.7 \mathrm{~Hz}, 2 \mathrm{H}), 6.74(\mathrm{~d}, J=8.8 \mathrm{~Hz}, 1 \mathrm{H})$, $6.56(\mathrm{~d}, J=2.8 \mathrm{~Hz}, 1 \mathrm{H}), 6.28(\mathrm{dd}, J=8.8,2.9 \mathrm{~Hz}, 1 \mathrm{H}), 4.92(\mathrm{~s}, 2 \mathrm{H}), 4.65(\mathrm{~s}, 2 \mathrm{H}), 3.62(\mathrm{~d}, J=5.8 \mathrm{~Hz}, 6 \mathrm{H})$. ${ }^{13} \mathrm{C}-\mathrm{NMR}\left(150 \mathrm{MHz}\right.$, DMSO- $\left.d_{6}\right) \delta: 172.18,161.67(\mathrm{~d}, J=241 \mathrm{~Hz}), 152.54,149.88,142.84,142.12,138.66$, $135.42,133.38(\times 2), 129.72,129.67,127.00,119.35,118.27,115.68,115.54,113.95,110.60,106.34,101.25$, $56.53,55.82,55.29,54.12,49.07$. HRMS calcd. for $\mathrm{C}_{26} \mathrm{H}_{22} \mathrm{FN}_{3} \mathrm{O}_{2} \mathrm{~S}$, [M+ Na] $]^{+}, 482.1314$; found 482.1375. HPLC: $t_{\mathrm{R}}=5.87 \mathrm{~min}, 97.66 \%$. 
N-(4-Fluorobenzyl)-3,4-dimethoxy-N-((4-(3-nitrophenyl)thiazol-2-yl)methyl)aniline (34). Light yellow solid, yield: $53.7 \%$ m.p. $120.5-121.6{ }^{\circ} \mathrm{C} .{ }^{1} \mathrm{H}-\mathrm{NMR}\left(600 \mathrm{MHz}, \mathrm{CDCl}_{3}\right)$ : $8.74(\mathrm{t}, J=1.9 \mathrm{~Hz}, 1 \mathrm{H})$, $8.21 \sim 8.16(\mathrm{~m}, 2 \mathrm{H}), 7.59(\mathrm{t}, J=8.0 \mathrm{~Hz}, 1 \mathrm{H}), 7.56(\mathrm{~s}, 1 \mathrm{H}), 7.32(\mathrm{dd}, J=8.5,5.4 \mathrm{~Hz}, 2 \mathrm{H}), 7.05 \sim 7.01(\mathrm{~m}, 2 \mathrm{H})$, $6.76 \sim 6.74(\mathrm{~m}, 1 \mathrm{H}), 6.56(\mathrm{~d}, J=2.1 \mathrm{~Hz}, 1 \mathrm{H}), 6.43(\mathrm{dd}, J=8.7,2.5 \mathrm{~Hz}, 1 \mathrm{H}), 4.80(\mathrm{~s}, 2 \mathrm{H}), 4.58(\mathrm{~s}, 2 \mathrm{H})$, $3.80(\mathrm{~s}, 3 \mathrm{H}), 3.76(\mathrm{~s}, 3 \mathrm{H}) .{ }^{13} \mathrm{C}-\mathrm{NMR}\left(150 \mathrm{MHz}, \mathrm{DMSO}-d_{6}\right) \delta: 172.21,161.68(\mathrm{~d}, J=240 \mathrm{~Hz}), 151.94,149.89$, 148.86, 142.85, 142.14, 136.09, 135.44, 132.50, 130.98, 129.72, 129.69, 123.00, 120.71, 117.40, 115.68, 115.54, $113.95,106.37,101.28,56.53,55.81,55.33,54.16$. HRMS calcd. for $\mathrm{C}_{25} \mathrm{H}_{22} \mathrm{FN}_{3} \mathrm{O}_{4} \mathrm{~S},[\mathrm{M}+\mathrm{Na}]^{+}, 502.1213$; found 502.1272. HPLC: $t_{\mathrm{R}}=6.87 \mathrm{~min}, 95.41 \%$.

N-(4-Fluorobenzyl)-3,4-dimethoxy-N-((4-(2-nitrophenyl)thiazol-2-yl)methyl)aniline (35). Light yellow oil, yield: 54.6\%. ${ }^{1} \mathrm{H}-\mathrm{NMR}\left(600 \mathrm{MHz}, \mathrm{DMSO}-d_{6}\right) \delta: 7.95(\mathrm{~s}, 1 \mathrm{H}), 7.90(\mathrm{dd}, J=8.0,1.0 \mathrm{~Hz}, 1 \mathrm{H})$, $7.83 \sim 7.78(\mathrm{~m}, 1 \mathrm{H}), 7.76 \sim 7.72(\mathrm{~m}, 1 \mathrm{H}), 7.64 \sim 7.60(\mathrm{~m}, 1 \mathrm{H}), 7.36(\mathrm{dd}, J=8.5,5.6 \mathrm{~Hz}, 2 \mathrm{H}), 7.18 \sim 7.12(\mathrm{~m}, 2 \mathrm{H})$, $6.74(\mathrm{~d}, J=8.8 \mathrm{~Hz}, 1 \mathrm{H}), 6.52(\mathrm{~d}, J=2.8 \mathrm{~Hz}, 1 \mathrm{H}), 6.27(\mathrm{dd}, J=8.8,2.8 \mathrm{~Hz}, 1 \mathrm{H}), 4.78(\mathrm{~s}, 2 \mathrm{H}), 4.59(\mathrm{~s}, 2 \mathrm{H})$, $3.63(\mathrm{~d}, J=10.9 \mathrm{~Hz}, 6 \mathrm{H}) .{ }^{13} \mathrm{C}-\mathrm{NMR}\left(150 \mathrm{MHz}, \mathrm{DMSO}-d_{6}\right) \delta: 171.08,161.68(\mathrm{~d}, J=241 \mathrm{~Hz}), 149.96,149.86$, $149.21,142.87,142.20,135.35,132.97,131.17,129.85,129.85,129.79,128.17,124.43,118.86,115.65,115.51$, $113.85,106.64,101.40,56.51,55.76,55.03,49.07$. HRMS calcd. for $\mathrm{C}_{25} \mathrm{H}_{22} \mathrm{FN}_{3} \mathrm{O}_{4} \mathrm{~S},[\mathrm{M}+\mathrm{Na}]^{+}, 502.1213$; found 502.1277. HPLC: $t_{\mathrm{R}}=5.44 \mathrm{~min}, 98.06 \%$.

N-((4-(4-Bromophenyl)thiazol-2-yl)methyl)-N-(4-fluorobenzyl)-3,4-dimethoxyaniline (36). Dark yellow oil, yield: $71.6 \% .{ }^{1} \mathrm{H}-\mathrm{NMR}\left(400 \mathrm{MHz}, \mathrm{DMSO}-\mathrm{d}_{6}\right) \delta: 8.06(\mathrm{~s}, 1 \mathrm{H}), 7.91(\mathrm{~d}, J=8.6 \mathrm{~Hz}, 2 \mathrm{H}), 7.64(\mathrm{~d}, J=8.6 \mathrm{~Hz}$, $2 \mathrm{H}), 7.38(\mathrm{dd}, J=8.5,5.7 \mathrm{~Hz}, 2 \mathrm{H}), 7.16(\mathrm{t}, J=8.9 \mathrm{~Hz}, 2 \mathrm{H}), 6.74(\mathrm{~d}, J=8.8 \mathrm{~Hz}, 1 \mathrm{H}), 6.56(\mathrm{~d}, J=2.7 \mathrm{~Hz}$, $1 \mathrm{H}), 6.27(\mathrm{dd}, J=8.8,2.8 \mathrm{~Hz}, 1 \mathrm{H}), 4.90(\mathrm{~s}, 2 \mathrm{H}), 4.65(\mathrm{~s}, 2 \mathrm{H}), 3.62(\mathrm{~d}, J=4.2 \mathrm{~Hz}, 6 \mathrm{H})$. ${ }^{13}$ C-NMR (150 MHz, DMSO- $\left.d_{6}\right) \delta: 171.65,161.67(\mathrm{~d}, J=240 \mathrm{~Hz}), 153.17,149.88,142.89,142.07$, $135.45,133.79,132.22(\times 2), 129.69,129.64,128.38(\times 2), 121.54,115.67,115.53(\times 2), 113.97,106.28,101.20$, 56.55, 55.81, 55.26, 54.16. HRMS calcd. for $\mathrm{C}_{25} \mathrm{H}_{22} \mathrm{BrFN}_{2} \mathrm{O}_{2} \mathrm{~S},[\mathrm{M}+\mathrm{Na}]^{+}$, 535.0467; found 535.0539. HPLC: $t_{\mathrm{R}}=11.61 \mathrm{~min}, 97.19 \%$.

N-(4-Fluorobenzyl)-3,4-dimethoxy-N-((4-(4-(1-methyl-1H-pyrazol-4-yl)phenyl)thiazol-2-yl)methyl)aniline (37). Brown solid, yield: $42.1 \%$. m.p. $126.1-130.3{ }^{\circ} \mathrm{C} .{ }^{1} \mathrm{H}-\mathrm{NMR}\left(600 \mathrm{MHz}, \mathrm{DMSO}-d_{6}\right) \delta: 8.18(\mathrm{~s}, 1 \mathrm{H})$, $7.96(\mathrm{~s}, 1 \mathrm{H}), 7.94 \sim 7.90(\mathrm{~m}, 3 \mathrm{H}), 7.63(\mathrm{~d}, J=8.4 \mathrm{~Hz}, 2 \mathrm{H}), 7.39(\mathrm{dd}, J=8.5,5.6 \mathrm{~Hz}, 2 \mathrm{H}), 7.16(\mathrm{t}, J=8.8 \mathrm{~Hz}$, $2 \mathrm{H}), 6.74(\mathrm{~d}, J=8.8 \mathrm{~Hz}, 1 \mathrm{H}), 6.57(\mathrm{~d}, J=2.8 \mathrm{~Hz}, 1 \mathrm{H}), 6.28(\mathrm{dd}, J=8.8,2.8 \mathrm{~Hz}, 1 \mathrm{H}), 4.91(\mathrm{~s}, 2 \mathrm{H}), 4.65(\mathrm{~s}, 2 \mathrm{H})$, $3.87(\mathrm{~s}, 3 \mathrm{H}), 3.62(\mathrm{~d}, J=9.6 \mathrm{~Hz}, 6 \mathrm{H}) .{ }^{13} \mathrm{C}-\mathrm{NMR}\left(150 \mathrm{MHz}, \mathrm{DMSO}-d_{6}\right) \delta: 170.07,160.59(\mathrm{~d}, J=240 \mathrm{~Hz})$, 153.23, 148.79, 141.88, 140.95, 135.47, 131.62, 131.44, 131.16, 130.91, 130.84, 128.56, 128.20, 128.12, 127.30, $125.77,124.57,120,89,114.59,114.45,112.90,105.18,100.11,55.48,54.73,54.17,53.13,47.99$. HRMS calcd. for $\mathrm{C}_{29} \mathrm{H}_{27} \mathrm{FN}_{4} \mathrm{O}_{2} \mathrm{~S},[\mathrm{M}+\mathrm{Na}]^{+}$, 537.1736; found 537.1822. HPLC: $t_{\mathrm{R}}=5.19 \mathrm{~min}, 95.89 \%$.

N-((4-(4-(3,5-Dimethylisoxazol-4-yl)phenyl)thiazol-2-yl)methyl)-N-(4-fluorobenzyl)-3,4-dimethoxyaniline (38). Yellow solid, yield: 51.6\%. m.p. $69.0-69.8{ }^{\circ} \mathrm{C} .{ }^{1} \mathrm{H}-\mathrm{NMR}\left(400 \mathrm{MHz}, \mathrm{DMSO}-d_{6}\right) \delta: 8.08 \sim 8.02(\mathrm{~m}, 3 \mathrm{H})$, $7.46(\mathrm{~d}, J=8.4 \mathrm{~Hz}, 2 \mathrm{H}), 7.39(\mathrm{dd}, J=8.5,5.6 \mathrm{~Hz}, 2 \mathrm{H}), 7.16(\mathrm{t}, J=8.9 \mathrm{~Hz}, 2 \mathrm{H}), 6.74(\mathrm{~d}, J=8.8 \mathrm{~Hz}, 1 \mathrm{H})$, $6.58(\mathrm{~d}, J=2.8 \mathrm{~Hz}, 1 \mathrm{H}), 6.29(\mathrm{dd}, J=8.8,2.8 \mathrm{~Hz}, 1 \mathrm{H}), 4.92(\mathrm{~s}, 2 \mathrm{H}), 4.66(\mathrm{~s}, 2 \mathrm{H}), 3.63(\mathrm{~d}, J=9.1 \mathrm{~Hz}, 6 \mathrm{H})$, $2.43(\mathrm{~s}, 3 \mathrm{H}), 2.26(\mathrm{~s}, 3 \mathrm{H}) .{ }^{13} \mathrm{C}-\mathrm{NMR}\left(150 \mathrm{MHz}, \mathrm{DMSO}-d_{6}\right) \delta: 171.35,165.67,161.68(\mathrm{~d}, J=240 \mathrm{~Hz}), 158.59$, $153.93,149.89,142.95,142.07,135.48,133.68,129.86,129.71(\times 2), 129.65,126.79(\times 2), 116.07,115.67$, $115.53,115.07,113.97,106.29,101.23,56.55,55.81,55.28,54.16,49.07,11.90,11.02$. HRMS calcd. for $\mathrm{C}_{30} \mathrm{H}_{28} \mathrm{FN}_{3} \mathrm{O}_{3} \mathrm{~S},[\mathrm{M}+\mathrm{Na}]^{+}, 552.1733$; found 552.1817. HPLC: $t_{\mathrm{R}}=7.26 \mathrm{~min}, 96.49 \%$.

N-(4-Fluorobenzyl)-3,4-dimethoxy-N-((4-(4-(1-methyl-1H-pyrazol-5-yl)phenyl)thiazol-2-yl)methyl)aniline (39). Dark yellow solid, yield: 49.0\%. m.p. 102.4-103. ${ }^{\circ} \mathrm{C} .{ }^{1} \mathrm{H}-\mathrm{NMR}\left(400 \mathrm{MHz}, \mathrm{DMSO}-d_{6}\right) \delta: 8.11(\mathrm{~s}, 1 \mathrm{H})$, $8.06(\mathrm{~d}, J=8.3 \mathrm{~Hz}, 2 \mathrm{H}), 7.62(\mathrm{~d}, J=8.3 \mathrm{~Hz}, 2 \mathrm{H}), 7.49(\mathrm{~d}, J=1.8 \mathrm{~Hz}, 1 \mathrm{H}), 7.40(\mathrm{dd}, J=8.4,5.7 \mathrm{~Hz}$, $2 \mathrm{H}), 7.17(\mathrm{t}, J=8.8 \mathrm{~Hz}, 2 \mathrm{H}), 6.75(\mathrm{~d}, J=8.8 \mathrm{~Hz}, 1 \mathrm{H}), 6.57(\mathrm{~d}, J=2.8 \mathrm{~Hz}, 1 \mathrm{H}), 6.47(\mathrm{~d}, J=1.8 \mathrm{~Hz}$, $1 \mathrm{H}), 6.29(\mathrm{dd}, J=8.8,2.8 \mathrm{~Hz}, 1 \mathrm{H}), 4.93(\mathrm{~s}, 2 \mathrm{H}), 4.67(\mathrm{~s}, 2 \mathrm{H}), 3.90(\mathrm{~s}, 3 \mathrm{H}), 3.63(\mathrm{~d}, J=5.9 \mathrm{~Hz}, 6 \mathrm{H})$. ${ }^{13}$ C-NMR (150 MHz, DMSO- $\left.d_{6}\right) \delta: 171.50,161.67(\mathrm{~d}, J=241 \mathrm{~Hz}), 153.73,149.88,142.93,142.78,142.06$, $138.44,135.47,134.38,130.02,129.71,129.66,129.27(\times 2), 126.67(\times 2), 115.68,115.54,115.48,113.98$, 
106.34, 106.29, 101.22, 56.56, 55.82, 55.28, 54.17, 49.07. HRMS calcd. for $\mathrm{C}_{29} \mathrm{H}_{27} \mathrm{FN}_{4} \mathrm{O}_{2} \mathrm{~S},[\mathrm{M}+\mathrm{Na}]^{+}$, 537.1736; found 537.1815. HPLC: $t_{\mathrm{R}}=5.84 \mathrm{~min}, 99.44 \%$.

N-(4-Fluorobenzyl)-3,4-dimethoxy-N-((4-(4-(thiophen-2-yl)phenyl)thiazol-2-yl)methyl)aniline (40). Dark yellow solid, yield: $43.7 \%$. m.p. $115.8-119.0{ }^{\circ} \mathrm{C} .{ }^{1} \mathrm{H}-\mathrm{NMR}\left(400 \mathrm{MHz}, \mathrm{DMSO}-d_{6}\right) \delta$ : $8.04(\mathrm{~s}, 1 \mathrm{H})$, $7.99(\mathrm{~d}, J=8.4 \mathrm{~Hz}, 2 \mathrm{H}), 7.74(\mathrm{~d}, J=8.4 \mathrm{~Hz}, 2 \mathrm{H}), 7.61 \sim 7.56(\mathrm{~m}, 2 \mathrm{H}), 7.39(\mathrm{dd}, J=8.4,5.7 \mathrm{~Hz}, 2 \mathrm{H})$, $7.20 \sim 7.14(\mathrm{~m}, 3 \mathrm{H}), 6.75(\mathrm{~d}, J=8.8 \mathrm{~Hz}, 1 \mathrm{H}), 6.57(\mathrm{~d}, J=2.7 \mathrm{~Hz}, 1 \mathrm{H}), 6.28(\mathrm{dd}, J=8.8,2.7 \mathrm{~Hz}$, 1H), $4.92(\mathrm{~s}, 2 \mathrm{H}), 4.66(\mathrm{~s}, 2 \mathrm{H}), 3.63(\mathrm{~d}, J=5.9 \mathrm{~Hz}, 6 \mathrm{H}) .{ }^{13} \mathrm{C}-\mathrm{NMR}\left(150 \mathrm{MHz}, \mathrm{DMSO}-d_{6}\right) \delta:$ 171.41, $161.68(\mathrm{~d}, J=241 \mathrm{~Hz}), 153.90,149.89,143.41,142.95,142.08,135.45,133.71,133.67,129.69,129.64$, 129.07, 127.05(×2), 126.31, 126.19(×2), 124.34, 115.67, 115.53, 114.84, 113.97, 106.31, 101.22, 56.54, 55.80, 55.28, 54.21. HRMS calcd. for $\mathrm{C}_{29} \mathrm{H}_{25} \mathrm{FN}_{2} \mathrm{O}_{2} \mathrm{~S}_{2}$, $[\mathrm{M}+\mathrm{Na}]^{+}, 539.1239$; found 539.1324. HPLC: $t_{\mathrm{R}}=13.67 \mathrm{~min}, 97.82 \%$.

$N$-(4-Fluorobenzyl)-3,4-dimethoxy-N-((4-(naphthalen-2-yl)thiazol-2-yl)methyl)aniline (41). Light yellow oil, yield: $76.1 \%$. ${ }^{1} \mathrm{H}-\mathrm{NMR}\left(400 \mathrm{MHz}, \mathrm{DMSO}-d_{6}\right) \delta: 8.54(\mathrm{~s}, 1 \mathrm{H}), 8.14 \sim 8.08(\mathrm{~m}, 2 \mathrm{H}), 7.98(\mathrm{t}, J=8.4 \mathrm{~Hz}$, $2 \mathrm{H}), 7.92(\mathrm{~d}, J=7.3 \mathrm{~Hz}, 1 \mathrm{H}), 7.57 \sim 7.48(\mathrm{~m}, 2 \mathrm{H}), 7.40(\mathrm{dd}, J=8.3,5.7 \mathrm{~Hz}, 2 \mathrm{H}), 7.17(\mathrm{t}, J=8.8 \mathrm{~Hz}, 2 \mathrm{H})$, $6.74(\mathrm{~d}, J=8.8 \mathrm{~Hz}, 1 \mathrm{H}), 6.60(\mathrm{~d}, J=2.6 \mathrm{~Hz}, 1 \mathrm{H}), 6.30(\mathrm{dd}, J=8.8,2.7 \mathrm{~Hz}, 1 \mathrm{H}), 4.95(\mathrm{~s}, 2 \mathrm{H}), 4.67(\mathrm{~s}, 2 \mathrm{H})$, $3.63(\mathrm{~d}, J=12.8 \mathrm{~Hz}, 6 \mathrm{H}) .{ }^{13} \mathrm{C}-\mathrm{NMR}\left(150 \mathrm{MHz}, \mathrm{DMSO}-d_{6}\right) \delta: 171.60,161.68(\mathrm{~d}, J=241 \mathrm{~Hz}), 154.35$, 149.90, 142.96, 142.09, 135.50, 133.66, 133.07, 132.04, 129.71, 129.66, 128.84, 128.70, 128.09, 127.04, 126.71, 125.03, 124.61, 115.69, 115.54, 115.28, 113.99, 106.32, 101.25, 56.55, 55.82, 55.31, 49.07. HRMS calcd. for $\mathrm{C}_{29} \mathrm{H}_{25} \mathrm{FN}_{2} \mathrm{O}_{2} \mathrm{~S},[\mathrm{M}+\mathrm{Na}]^{+}$, 507.1518; found 507.1588. HPLC: $t_{\mathrm{R}}=11.73 \mathrm{~min}, 96.23 \%$.

$N$-(4-Fluorobenzyl)-3,4-dimethoxy-N-((4-(p-tolyl)thiazol-2-yl)methyl)aniline (42). Yellow solid, yield: $67.1 \%$. m.p. 105.3-107.0 ${ }^{\circ} \mathrm{C} .{ }^{1} \mathrm{H}-\mathrm{NMR}\left(400 \mathrm{MHz}, \mathrm{DMSO}-d_{6}\right) \delta: 7.90(\mathrm{~s}, 1 \mathrm{H}), 7.85(\mathrm{~d}, J=8.1 \mathrm{~Hz}, 2 \mathrm{H})$, $7.38(\mathrm{dd}, J=8.5,5.7 \mathrm{~Hz}, 2 \mathrm{H}), 7.25(\mathrm{~d}, J=8.0 \mathrm{~Hz}, 2 \mathrm{H}), 7.16(\mathrm{t}, J=8.9 \mathrm{~Hz}, 2 \mathrm{H}), 6.74(\mathrm{~d}, J=8.8 \mathrm{~Hz}$, $1 \mathrm{H}), 6.57(\mathrm{~d}, J=2.8 \mathrm{~Hz}, 1 \mathrm{H}), 6.27(\mathrm{dd}, J=8.8,2.8 \mathrm{~Hz}, 1 \mathrm{H}), 4.90(\mathrm{~s}, 2 \mathrm{H}), 4.65(\mathrm{~s}, 2 \mathrm{H}), 3.62(\mathrm{~d}, J=5.9 \mathrm{~Hz}$, 6H), 2.33 (s, 3H). ${ }^{13} \mathrm{C}-\mathrm{NMR}(150 \mathrm{MHz}$, DMSO-d 6 ) $\delta: 171.06,161.67(\mathrm{~d}, J=240 \mathrm{~Hz}), 160.87,154.50,149.87$, 142.97, 142.03, 137.76, 135.48, 131.97, 129.82(×2), 129.67, 129.62(×2), 126.31, 115.66, 115.52, 113.98, $113.75,106.25,101.17,56.55,55.78,55.25,54.21,21.28$. HRMS calcd. for $\mathrm{C}_{26} \mathrm{H}_{25} \mathrm{FN}_{2} \mathrm{O}_{2} \mathrm{~S},[\mathrm{M}+\mathrm{Na}]^{+}$, 471.1518; found 471.1578. HPLC: $t_{\mathrm{R}}=9.58 \mathrm{~min}, 97.85 \%$.

$\mathrm{N}$-(4-Fluorobenzyl)-3,4-dimethoxy-N-((4-(4-methoxyphenyl)thiazol-2-yl)methyl)aniline (43). Dark yellow solid, yield: $83.7 \%$. m.p. $76.3-79.0{ }^{\circ} \mathrm{C} .{ }^{1} \mathrm{H}-\mathrm{NMR}\left(400 \mathrm{MHz}, \mathrm{DMSO}-d_{6}\right) \delta: 7.88(\mathrm{~d}, J=8.8 \mathrm{~Hz}$, $2 \mathrm{H}), 7.82(\mathrm{~s}, 1 \mathrm{H}), 7.39(\mathrm{dd}, J=8.5,5.7 \mathrm{~Hz}, 2 \mathrm{H}), 7.16(\mathrm{t}, J=8.8 \mathrm{~Hz}, 2 \mathrm{H}), 7.00(\mathrm{~d}, J=8.8 \mathrm{~Hz}$, $2 \mathrm{H}), 6.74(\mathrm{~d}, J=8.8 \mathrm{~Hz}, 1 \mathrm{H}), 6.56(\mathrm{~d}, J=2.8 \mathrm{~Hz}, 1 \mathrm{H}), 6.27(\mathrm{dd}, J=8.8,2.8 \mathrm{~Hz}, 1 \mathrm{H}), 4.89(\mathrm{~s}, 2 \mathrm{H})$, $4.65(\mathrm{~s}, 2 \mathrm{H}), 3.80(\mathrm{~s}, 3 \mathrm{H}), 3.62(\mathrm{~d}, J=4.0 \mathrm{~Hz}, 6 \mathrm{H}) .{ }^{13} \mathrm{C}-\mathrm{NMR}\left(150 \mathrm{MHz}, \mathrm{DMSO}-d_{6}\right) \delta:$ 170.93, $161.67(\mathrm{~d}, J=241 \mathrm{~Hz}), 159.56,154.34,149.88,142.99,142.03,135.48,129.67,129.61,127.73(\times 2), 127.48$, $115.66,115.52,114.60(\times 2), 113.98,112.54,106.25,101.17,56.54,55.79,55.60,55.25,54.20$. HRMS calcd. for $\mathrm{C}_{26} \mathrm{H}_{25} \mathrm{FN}_{2} \mathrm{O}_{3} \mathrm{~S}$, $[\mathrm{M}+\mathrm{Na}]^{+}$, 487.1468; found 487.1535. HPLC: $t_{\mathrm{R}}=7.05 \mathrm{~min}, 98.64 \%$.

$\mathrm{N}$-((4-(4-Aminophenyl)thiazol-2-yl)methyl)-N-(4-fluorobenzyl)-3,4-dimethoxyaniline (44). Light yellow solid, yield: $87.3 \%$. m.p. $144.7-146.2{ }^{\circ} \mathrm{C} .{ }^{1} \mathrm{H}-\mathrm{NMR}\left(400 \mathrm{MHz}, \mathrm{DMSO}-d_{6}\right) \delta: 7.61(\mathrm{~d}, J=8.5 \mathrm{~Hz}, 2 \mathrm{H})$, $7.55(\mathrm{~s}, 1 \mathrm{H}), 7.40 \sim 7.36(\mathrm{~m}, 2 \mathrm{H}), 7.16(\mathrm{dd}, J=12.3,5.4 \mathrm{~Hz}, 2 \mathrm{H}), 6.74(\mathrm{~d}, J=8.8 \mathrm{~Hz}, 1 \mathrm{H}), 6.60(\mathrm{~d}, J=8.6 \mathrm{~Hz}$, $2 \mathrm{H}), 6.55(\mathrm{~d}, J=2.8 \mathrm{~Hz}, 1 \mathrm{H}), 6.25(\mathrm{dd}, J=8.8,2.8 \mathrm{~Hz}, 1 \mathrm{H}), 5.28(\mathrm{~s}, 2 \mathrm{H}), 4.86(\mathrm{~s}, 2 \mathrm{H}), 4.64(\mathrm{~s}, 2 \mathrm{H})$, $3.62(\mathrm{~d}, J=4.2 \mathrm{~Hz}, 6 \mathrm{H}) .{ }^{13} \mathrm{C}-\mathrm{NMR}\left(150 \mathrm{MHz}, \mathrm{DMSO}-d_{6}\right) \delta: 170.23,161.65(\mathrm{~d}, J=241 \mathrm{~Hz}), 155.52,149.86$, $149.12,143.04,141.95,135.54,129.65,129.60,127.41(\times 2), 122.83,115.65,115.51,114.27(\times 2), 114.00$, 109.74, 106.17, 101.11, 56.57, 55.78, 55.21, 54.23. HRMS calcd. for $\mathrm{C}_{25} \mathrm{H}_{24} \mathrm{FN}_{3} \mathrm{O}_{2} \mathrm{~S}$, [M + Na] $]^{+}, 472.1471$; found 472.1538 . HPLC: $t_{\mathrm{R}}=4.25 \mathrm{~min}, 95.78 \%$.

N-(4-(2-(((3,4-Dimethoxyphenyl)(4-fluorobenzyl)amino)methyl)thiazol-4-yl)phenyl)-2,2,2-trifluoroacetamide (45). Light yellow solid, yield: 75.8\%. m.p. $143.6-145.8{ }^{\circ} \mathrm{C} .{ }^{1} \mathrm{H}-\mathrm{NMR}\left(600 \mathrm{MHz}, \mathrm{DMSO}-d_{6}\right) \delta: 11.34$ $(\mathrm{s}, 1 \mathrm{H}), 8.01 \sim 7.96(\mathrm{~m}, 3 \mathrm{H}), 7.76(\mathrm{~d}, J=8.7 \mathrm{~Hz}, 2 \mathrm{H}), 7.38(\mathrm{dd}, J=8.4,5.7 \mathrm{~Hz}, 2 \mathrm{H}), 7.16(\mathrm{t}, J=8.8 \mathrm{~Hz}, 2 \mathrm{H})$, $6.74(\mathrm{~d}, J=8.8 \mathrm{~Hz}, 1 \mathrm{H}), 6.56(\mathrm{~d}, J=2.8 \mathrm{~Hz}, 1 \mathrm{H}), 6.28(\mathrm{dd}, J=8.8,2.8 \mathrm{~Hz}, 1 \mathrm{H}), 4.90(\mathrm{~s}, 2 \mathrm{H}), 4.65(\mathrm{~s}, 2 \mathrm{H})$, $3.62(\mathrm{~d}, J=6.5 \mathrm{~Hz}, 6 \mathrm{H}) .{ }^{13} \mathrm{C}-\mathrm{NMR}\left(150 \mathrm{MHz}, \mathrm{DMSO}-d_{6}\right) \delta: 171.42,161.67(\mathrm{~d}, J=240 \mathrm{~Hz}), 155.02$, 
154.78, 153.72, 149.88, 142.93, 142.06, 136.43, 135.47, 131.92, 129.69, 129.64, 126.95(×2), 121.69, 115.67, $115.53,114.62,113.98,106.28,101.20,56.55,55.80,55.26,54.19,49.06$. HRMS calcd. for $\mathrm{C}_{27} \mathrm{H}_{23} \mathrm{~F}_{4} \mathrm{~N}_{3} \mathrm{O}_{3} \mathrm{~S}$, $[\mathrm{M}+\mathrm{Na}]^{+}, 568.1294$; found 568.1379. HPLC: $t_{\mathrm{R}}=5.34 \mathrm{~min}, 97.66 \%$.

N-(4-(2-(((3,4-Dimethoxyphenyl)(4-fluorobenzyl)amino)methyl)thiazol-4-yl)phenyl)acetamide (46). Light yellow solid, yield: 86.1\%. m.p. 134.6-137.0 ${ }^{\circ} \mathrm{C} .{ }^{1} \mathrm{H}-\mathrm{NMR}$ (600 MHz, DMSO- $\left.d_{6}\right)$ 8: 10.03 (s, 1H), $7.88 \sim 7.83(\mathrm{~m}, 3 \mathrm{H}), 7.64(\mathrm{~d}, J=8.6 \mathrm{~Hz}, 2 \mathrm{H}), 7.38(\mathrm{dd}, J=8.4,5.7 \mathrm{~Hz}, 2 \mathrm{H}), 7.16(\mathrm{t}, J=8.8 \mathrm{~Hz}$, $2 \mathrm{H}), 6.74(\mathrm{~d}, J=8.8 \mathrm{~Hz}, 1 \mathrm{H}), 6.55(\mathrm{~d}, J=2.8 \mathrm{~Hz}, 1 \mathrm{H}), 6.27(\mathrm{dd}, J=8.8,2.8 \mathrm{~Hz}, 1 \mathrm{H}), 4.89(\mathrm{~s}, 2 \mathrm{H})$, $4.64(\mathrm{~s}, 2 \mathrm{H}), 3.62(\mathrm{~d}, J=6.2 \mathrm{~Hz}, 6 \mathrm{H}), 2.06(\mathrm{~s}, 3 \mathrm{H}) .{ }^{13} \mathrm{C}-\mathrm{NMR}\left(150 \mathrm{MHz}, \mathrm{DMSO}-d_{6}\right) \delta: 171.06,168.81$, $161.66(\mathrm{~d}, J=241 \mathrm{~Hz}), 154.29,149.87,142.95,142.03,139.57,135.48,129.69,129.63,129.48,126.81(\times 2)$, 119.49(×2), 115.66, 115.52, 113.98, 113.25, 106.26, 101.18, 56.55, 55.80, 55.24, 54.20, 49.07. HRMS calcd. for $\mathrm{C}_{27} \mathrm{H}_{26} \mathrm{FN}_{3} \mathrm{O}_{3} \mathrm{~S}$, $[\mathrm{M}+\mathrm{Na}]^{+}$, 514.1577; found 514.1662. HPLC: $t_{\mathrm{R}}=3.84 \mathrm{~min}, 97.51 \%$.

Methyl(4-(2-(((3,4-dimethoxyphenyl)(4-fluorobenzyl)amino)methyl)thiazol-4-yl)phenyl)glycinate (47). Light yellow solid, yield: 79.4\%. m.p. $103.5-105.4{ }^{\circ} \mathrm{C} .{ }^{1} \mathrm{H}-\mathrm{NMR}\left(600 \mathrm{MHz}, \mathrm{DMSO}-d_{6}\right) \delta: 7.67(\mathrm{~d}, J=8.6 \mathrm{~Hz}$, $2 \mathrm{H}), 7.59(\mathrm{~s}, 1 \mathrm{H}), 7.37(\mathrm{dd}, J=8.5,5.6 \mathrm{~Hz}, 2 \mathrm{H}), 7.15(\mathrm{t}, J=8.8 \mathrm{~Hz}, 2 \mathrm{H}), 6.73(\mathrm{~d}, J=8.8 \mathrm{~Hz}, 1 \mathrm{H})$, $6.60(\mathrm{~d}, J=8.7 \mathrm{~Hz}, 2 \mathrm{H}), 6.54(\mathrm{~d}, J=2.8 \mathrm{~Hz}, 1 \mathrm{H}), 6.27 \sim 6.22(\mathrm{~m}, 2 \mathrm{H}), 4.86(\mathrm{~s}, 2 \mathrm{H}), 4.63(\mathrm{~s}, 2 \mathrm{H})$, $3.96(\mathrm{~d}, J=6.4 \mathrm{~Hz}, 2 \mathrm{H}), 3.66(\mathrm{~s}, 3 \mathrm{H}), 3.61(\mathrm{~d}, J=5.2 \mathrm{~Hz}, 6 \mathrm{H}) .{ }^{13} \mathrm{C}-\mathrm{NMR}\left(150 \mathrm{MHz}, \mathrm{DMSO}-d_{6}\right) \delta: 172.19$, $170.39,161.65(\mathrm{~d}, J=240 \mathrm{~Hz}), 155.25,149.85,148.47,143.02,141.95,135.53,129.66,129.61,127.37(\times 2)$, $123.48,115.65,115.51,114.00,112.55,110.26,106.18,101.12,56.57,55.79,55.20,54.22,52.11,49.07,44.89$. HRMS calcd. for $\mathrm{C}_{28} \mathrm{H}_{28} \mathrm{FN}_{3} \mathrm{O}_{4} \mathrm{~S}$, [M + Na] $]^{+}$, 544.1682; found 544.1757. HPLC: $t_{\mathrm{R}}=4.77 \mathrm{~min}, 95.90 \%$.

Ethyl-4-(4-(2-(((3,4-dimethoxyphenyl)(4-fluorobenzyl)amino)methyl)thiazol-4-yl)phenoxy)butanoate (48). yellow oil, yield: $32.9 \% .{ }^{1} \mathrm{H}-\mathrm{NMR}\left(400 \mathrm{MHz}, \mathrm{DMSO}-d_{6}\right) \delta: 7.86(\mathrm{~d}, J=8.6 \mathrm{~Hz}, 2 \mathrm{H}), 7.81(\mathrm{~s}, 1 \mathrm{H})$, $7.38(\mathrm{dd}, J=8.3,5.8 \mathrm{~Hz}, 2 \mathrm{H}), 7.16(\mathrm{t}, J=8.8 \mathrm{~Hz}, 2 \mathrm{H}), 6.98(\mathrm{~d}, J=8.8 \mathrm{~Hz}, 2 \mathrm{H}), 6.74(\mathrm{~d}, J=8.8 \mathrm{~Hz}, 1 \mathrm{H})$, $6.55(\mathrm{~d}, J=2.6 \mathrm{~Hz}, 1 \mathrm{H}), 6.27(\mathrm{dd}, J=8.8,2.7 \mathrm{~Hz}, 1 \mathrm{H}), 4.89(\mathrm{~s}, 2 \mathrm{H}), 4.64(\mathrm{~s}, 2 \mathrm{H}), 4.08(\mathrm{q}, J=7.1 \mathrm{~Hz}$, $2 \mathrm{H}), 4.03(\mathrm{t}, J=6.3 \mathrm{~Hz}, 2 \mathrm{H}), 3.62(\mathrm{~d}, J=3.7 \mathrm{~Hz}, 6 \mathrm{H}), 2.47(\mathrm{t}, J=7.3 \mathrm{~Hz}, 2 \mathrm{H}), 2.03 \sim 1.95(\mathrm{~m}, 2 \mathrm{H})$, $1.19(\mathrm{t}, J=7.1 \mathrm{~Hz}, 3 \mathrm{H}) .{ }^{13} \mathrm{C}-\mathrm{NMR}\left(150 \mathrm{MHz}, \mathrm{DMSO}-d_{6}\right) \delta: 173.04,170.93,161.67(\mathrm{~d}, J=240 \mathrm{~Hz}), 158.77$, $154.31,149.87,142.98,142.01,135.50,129.68,129.62,127.73(\times 2), 127.50,115.67,115.53,115.09(\times 2)$, $113.99,112.57,106.23,101.16,67.00,60.36,56.56,55.79,55.24,54.19,30.61,24.70,14.58$. HRMS calcd. for $\mathrm{C}_{31} \mathrm{H}_{33} \mathrm{FN}_{2} \mathrm{O}_{5} \mathrm{~S}$, $[\mathrm{M}+\mathrm{Na}]^{+}$, 587.1992; found 587.2083. HPLC: $t_{\mathrm{R}}=8.39 \mathrm{~min}, 96.53 \%$.

$\mathrm{N}$-(4-Fluorobenzyl)-3,4-dimethoxy-N-((4-(4-morpholinophenyl)thiazol-2-yl)methyl)aniline (49). White solid, yield: $53.7 \%$. m.p. 139.0-140.4 ${ }^{\circ} \mathrm{C} .{ }^{1} \mathrm{H}-\mathrm{NMR}\left(600 \mathrm{MHz}, \mathrm{DMSO}_{6}\right) \quad \delta: 7.81 \sim 7.78(\mathrm{~m}, 2 \mathrm{H})$, $7.74(\mathrm{~s}, 1 \mathrm{H}), 7.38(\mathrm{dd}, J=8.6,5.6 \mathrm{~Hz}, 2 \mathrm{H}), 7.17 \sim 7.14(\mathrm{~m}, 2 \mathrm{H}), 6.99(\mathrm{~d}, J=9.0 \mathrm{~Hz}, 2 \mathrm{H})$, $6.73(\mathrm{~d}, J=8.8 \mathrm{~Hz}, 1 \mathrm{H}), 6.55(\mathrm{~d}, J=2.8 \mathrm{~Hz}, 1 \mathrm{H}), 6.26(\mathrm{dd}, J=8.8,2.9 \mathrm{~Hz}, 1 \mathrm{H}), 4.88(\mathrm{~s}, 2 \mathrm{H}), 4.64(\mathrm{~s}, 2 \mathrm{H})$, $3.76 \sim 3.73(\mathrm{~m}, 4 \mathrm{H}), 3.61(\mathrm{~d}, J=5.7 \mathrm{~Hz}, 6 \mathrm{H}), 3.17 \sim 3.14(\mathrm{~m}, 4 \mathrm{H}) .{ }^{13} \mathrm{C}-\mathrm{NMR}\left(150 \mathrm{MHz}\right.$, DMSO- $\left.d_{6}\right) \delta: 170.13$, $161.08(\mathrm{~d}, J=241 \mathrm{~Hz}), 154.11,150.51,149.28,142.42,141.41,134.93,129.09,129.04,126.65(\times 2), 125.16$, $115.08,114.44,114.20(\times 2), 113.42,111.12,105.63,100.56,65.93(\times 2), 55.99,55.21,54.65,53.64,48.49,47.92$. HRMS calcd. for $\mathrm{C}_{29} \mathrm{H}_{30} \mathrm{FN}_{3} \mathrm{O}_{3} \mathrm{~S}$, [M + Na] $]^{+}$, 542.1890; found 542.1975. HPLC: $t_{\mathrm{R}}=6.29 \mathrm{~min}, 98.33 \%$.

\subsection{In Vitro CETP Inhibitory Assay}

All tested compounds were dissolved in 100\% DMSO. The compound was dissolved totally, and the solution was vibrated hard on an oscillator for more than $30 \mathrm{~s}$ and then stored in a nitrogen cabinet. The stock solutions $(10 \mathrm{mM})$ were diluted with DMSO for an eight-point titration (1:5 serial dilutions) in a 96-well dilution plate. The activity was estimated in accordance with the instructions for the CETP inhibitor screening kit and recombinant CETP. The compounds were tested at eight concentrations, and the fluorescence intensities were measured using a fluorometer $(\mathrm{ExEm}=465 / 535 \mathrm{~nm})$. The $\mathrm{IC}_{50}$ was determined from a curve fit of the data with each concentration tested three times. 


\subsection{Metabolic Stability Study}

Ten microliters $(10 \mu \mathrm{L}, 100 \mu \mathrm{M} / \mathrm{L})$ of compounds and $80 \mu \mathrm{L}$ of liver microsomes were mixed and incubated at $37{ }^{\circ} \mathrm{C}$ for $10 \mathrm{~min}$, and then $10 \mu \mathrm{L}$ of NADPH regenerating system was added. Samples were obtained at $0 \mathrm{~min}, 5 \mathrm{~min}, 10 \mathrm{~min}, 20 \mathrm{~min}, 30 \mathrm{~min}$ and $60 \mathrm{~min}$. respectively, and $300 \mu \mathrm{L}$ stop solution (cold in $4{ }^{\circ} \mathrm{C}$, including $100 \mathrm{ng} / \mathrm{mL}$ tolbutamide and $100 \mathrm{ng} / \mathrm{mL}$ labetalol) was added to terminate the reaction. After oscillating for $10 \mathrm{~min}$, the plates were centrifuged (4000 rpm) at room temperature for $20 \mathrm{~min}$, and the supernatants were used for analysis.

\section{Conclusions}

A series of $\mathrm{N}, \mathrm{N}$-disubstituted-4-arylthiazole-2-methylamine derivatives were designed, synthesized, and evaluated for their inhibitory activity against CETP by a BODIPY-CE fluorescence assay. Compounds 30 and $\mathbf{3 2}$ displayed substantial CETP inhibitory activity in vitro with $\mathrm{IC}_{50}$ values of $0.79 \pm 0.02 \mu \mathrm{M}$ and $0.97 \pm 0.01 \mu \mathrm{M}$, respectively, and demonstrated weak human/rat liver microsome stability. This suggests that compounds $\mathbf{3 0}$ and $\mathbf{3 2}$ could act as potential CETP inhibitors to be used for further optimization.

Supplementary Materials: Supplementary materials are available online.

Acknowledgments: We gratefully acknowledge the financial support from the National Natural Science Foundation of China (Grant No. 81373324), the National Science Fund for Fostering Talents in Basic Science (Grant No. J1103606), the Program for Innovative Research Team of the Ministry of Education, and the Program for Innovative Research Team at Liaoning University.

Author Contributions: Xinran Wang and Xuehua Lin are co-authors; they contributed equally to the work. They designed and carried out the experiments and wrote the paper; Xuanqi Xu, Wei Li, Lijuan Hao, and Chunchi Liu assisted in the experiment; and Dongmei Zhao and Maosheng Cheng supervised the whole experiment and provided technical guidance. All authors have read and approved the final manuscript.

Conflicts of Interest: The authors declare no conflicts of interest.

\section{References}

1. Jafri, H.; Alsheikh-Ali, A.A.; Karas, R.H. Meta-analysis: Statin therapy does not alter the association between low levels of high-density lipoprotein cholesterol and increased cardiovascular risk. Ann. Intern. Med. 2010, 153, 800-808. [CrossRef] [PubMed]

2. De Backer, G. European guidelines on cardiovascular disease prevention in clinical practice Third Joint Task Force of European and other Societies on Cardiovascular Disease Prevention in Clinical Practice (constituted by representatives of eight societies and by invited experts). Eur. Heart J. 2003, 24, 1601-1610. [PubMed]

3. Barter, P.; Gotto, A.M.; LaRosa, J.C.; Maroni, J.; Szarek, M.; Grundy, S.M.; Kastelein, J.J.; Bittner, V.; Fruchart, J.C. HDL cholesterol, very low levels of LDL cholesterol, and cardiovascular events. N. Engl. J. Med. 2007, 357, 1301-1310. [CrossRef] [PubMed]

4. Sharrett, A.R.; Ballantyne, C.M.; Coady, S.A.; Heiss, G.; Sorlie, P.D.; Catellier, D.; Patsch, W. Coronary heart disease prediction from lipoprotein cholesterol levels, triglycerides, lipoprotein(a), apolipoproteins A-I and B, and HDL densitynsubfractions: The Atherosclerosis Risk in Communities (ARIC) Study. Circulation 2001, 104, 1108-1113. [CrossRef] [PubMed]

5. McGovern, P.G.; Pankow, J.S.; Shahar, E.; Doliszny, K.M.; Folsom, A.R.; Blackburn, H.; Luepker, R.V. Recent trends in acute coronary heart disease-Mortality, morbidity, medical care, and risk factors. N. Eng. J. Med. 1996, 334, 884-890. [CrossRef] [PubMed]

6. Curb, J.D.; Abbott, R.D.; Rodriguez, B.L.; Masaki, K.; Chen, R.; Sharp, D.S.; Tall, A.R. A prospective study of HDL-C and cholesteryl ester transfer protein gene mutations and the risk of coronary heart disease in the elderly. J. Lipid Res. 2004, 45, 948-953. [CrossRef] [PubMed]

7. Baigent, C.; Blacwell, L.; Emberson, J.; Holland, L.E.; Reith, C.; Bhala, N.; Peto, R.; Barnes, E.H.; Keech, A.; Simes, J.; et al. Efficacy and safety of more intensive lowering of LDL cholesterol: A meta-analysis of data from 170,000 participants in 26 randomised trials. Lancet 2010, 376, 1670-1681. [PubMed] 
8. Brunzell, J.D.; Davidson, M.; Furberg, C.D.; Goldberg, R.B.; Howard, B.V.; Stein, J.H.; Witztum, J.L.; American Diabetes Association; American College of Cardiology Foundation. Lipoprotein management in patients with cardiometabolic risk. Diabetes Care 2008, 31, 811-822. [CrossRef] [PubMed]

9. Baigent, C.; Keech, A.; Kearney, P.M.; Blackwell, L.; Buck, G.; Pollicino, C.; Kirby, A.; Sourjina, T.; Peto, R.; Collins, R.; et al. Efficacy and safety of cholesterol-lowering treatment: Prospective meta-analysis of data from 90,056 participants in 14 randomised trials of statins. Lancet 2005, 366, 1267-1268. [PubMed]

10. Lavigne, P.M.; Karas, R.H. The current state of niacin in cardiovascular disease prevention: A systematic review and meta-regression. J. Am. Coll. Cardiol. 2013, 61, 440-446. [CrossRef] [PubMed]

11. Mantlo, N.B.; Escribano, A. Update on the discovery and development of cholesteryl ester transfer protein inhibitors for reducing residual cardiovascular risk. J. Med. Chem. 2014, 57, 1-17. [CrossRef] [PubMed]

12. Barter, P.J.; Rye, K.A. Cholesteryl ester transfer protein inhibition as a strategy to reduce cardiovascular risk. J. Lipid Res. 2012, 53, 1755-1766. [CrossRef] [PubMed]

13. Barter, P.J.; Rye, K.A.; Beltangady, M.S.; Ports, W.C.; Duggan, W.T.; Boekholdt, S.M.; DeMicco, D.A.; Kastelein, J.J.; Shear, C.L. Relationship between atorvastatin dose and the harm caused by torcetrapib. J. Lipid Res. 2012, 53, 2436-2442. [CrossRef] [PubMed]

14. Johns, D.G.; Duffy, J.; Fisher, T.; Hubbard, B.K.; Forrest, M.J. On- and off-target pharmacology of torcetrapib current understanding and implications for the structure activity relationships (SAR), discovery and development of cholesteryl ester-transfer protein (CETP) inhibitors. Drugs 2012, 72, 491-507. [CrossRef] [PubMed]

15. Schwartz, G.G.; Olsson, A.G.; Abt, M.; Ballantyne, C.M.; Barter, P.J.; Brumm, J.; Chaitman, B.R.; Holme, I.M.; Kallend, D.; Leiter, L.A.; et al. Effects of dalcetrapib in patients with a recent acute coronary syndrome. N. Engl. J. Med. 2012, 367, 2089-2099. [CrossRef] [PubMed]

16. Hisashi, S.; Kimiya, M.; Takahiro, Y.; Hiroshi, O.; Itsuo, U. Bis(2-(Acylamino)phenyl) disulfides, 2-(acylamino)benzenethiols, and S-(2-(acylamino)phenyl) alkanethioates as novel inhibitors of cholesteryl ester transfer protein. J. Med. Chem. 2000, 43, 3566-3572.

17. Nicholls, S.J.; Brewer, H.B.; Kastelein, J.J.; Kathryn, K.A.; Wang, M.D.; Shao, M.; Hu, B.; McErlean, E.; Nissen, S.E. Effects of the CETP inhibitor evacetrapib administered as monotherapy or in combination with statins on HDL and LDL cholesterol. JAMA 2011, 306, 2099-2109. [CrossRef] [PubMed]

18. Hovingh, G.K.; Kastelein, J.J.; van Deventer, S.J.; Round, P.; Ford, J.; Saleheen, D.; Rader, D.J.; Brewer, H.B.; Barter, P.J. Cholesterol ester transfer protein inhibition by TA-8995 in patients with mild dyslipidaemia (TULIP): A randomised, double-blind, placebo-zcontrolled phase 2 trial. Lancet 2015, 386, 452-460. [CrossRef]

Sample Availability: Samples of the compounds $17 \mathrm{a}-\mathbf{1 7 g}, \mathbf{2 1 - 4 9}$ are available from the authors.

(C) 2017 by the authors. Licensee MDPI, Basel, Switzerland. This article is an open access article distributed under the terms and conditions of the Creative Commons Attribution (CC BY) license (http:/ / creativecommons.org/licenses/by/4.0/). 